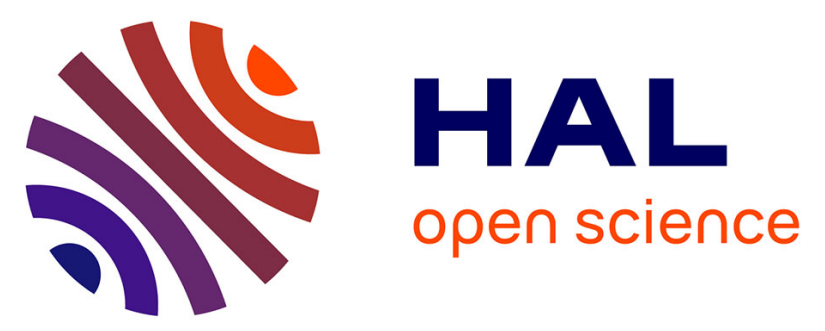

\title{
MEASURING THE DECLINE OF A MARSHALLIAN INDUSTRIAL DISTRICT: THE BIRMINGHAM JEWELLERY QUARTER
}

\author{
Lisa de Propris, Luciana Lazzeretti
}

\section{- To cite this version:}

Lisa de Propris, Luciana Lazzeretti. MEASURING THE DECLINE OF A MARSHALLIAN INDUSTRIAL DISTRICT: THE BIRMINGHAM JEWELLERY QUARTER. Regional Studies, 2009, 43 (09), pp.1135-1154. 10.1080/00343400802070894 . hal-00526545

HAL Id: hal-00526545

https://hal.science/hal-00526545

Submitted on 15 Oct 2010

HAL is a multi-disciplinary open access archive for the deposit and dissemination of scientific research documents, whether they are published or not. The documents may come from teaching and research institutions in France or abroad, or from public or private research centers.
L'archive ouverte pluridisciplinaire HAL, est destinée au dépôt et à la diffusion de documents scientifiques de niveau recherche, publiés ou non, émanant des établissements d'enseignement et de recherche français ou étrangers, des laboratoires publics ou privés. 


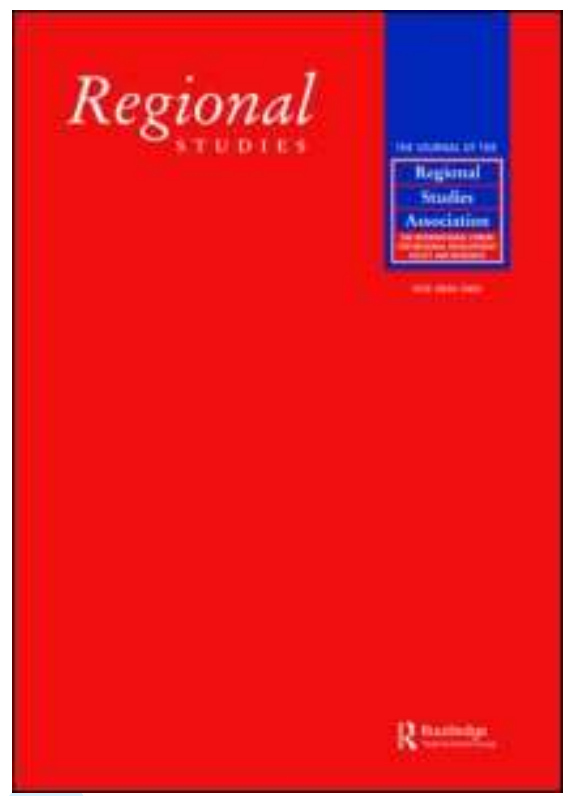

\section{MEASURING THE DECLINE OF A MARSHALLIAN INDUSTRIAL DISTRICT: \\ THE BIRMINGHAM JEWELLERY QUARTER}

\begin{tabular}{|r|l|}
\hline Journal: & Regional Studies \\
\hline Manuscript ID: & CRES-2006-0307.R2 \\
\hline Manuscript Type: & Main Section \\
\hline JEL codes: & $\begin{array}{l}\text { L22 - Firm Organization, Market Structure: Markets vs. Hierarchies; } \\
\text { Vertical Integration < L2 - Firm Objectives, Organization, and } \\
\text { Behavior < L - Industrial Organization, N01 - Development of the } \\
\text { - Economic History, O14 - Industrialization; Manufacturing; Service } \\
\text { Industries; Tech Choice < O1 - Economic Development < O - } \\
\text { Economic Development, Technological Change, and Growth }\end{array}$ \\
\hline Keywords: & industrial district, firm demography, firm ecology, cluster lif cycle \\
\hline
\end{tabular}

\section{SCHOLARONE \\ Manuscripts}




\title{
MEASURING THE DECLINE OF A MARSHALLIANINDUSTRIAL DISTRICT: THE BIRMINGHAMJEWELLERY QUARTER
}

\author{
Lisa De Propris` and Luciana Lazzeretti \\ - The University of Birmingham \\ - The University of Florence \\ First received: December 2006 \\ Accepted: December 2007
}

\begin{abstract}
This paper presents the findings of a study on the decline of a typical Marshallian industrial district: the Birmingham Jewellery Quarter (UK). The paper contributes to the current debate on clusters' life cycle, by presenting a multidisciplinary methodology that combines historical and economic analyses with demography and organisational ecology models. We seek to explore the patterns of firms' birth and mortality rates, as well as firm density across branches of production activities to measure and understand the decline of the Jewellery Quarter over the last decades.
\end{abstract}

Key words: Marshallian industrial districts, cluster life cycle and ecological theory. JEL classification: L23, N80 and O14

Mesurer le déclin d'un district industriel du type Marshall: le quartier de la bijouterie à Birmingham.

De Propris \& Lazzeretti

Cet article cherche à présenter les résultats provenant d'une étude au sujet du déclin d'un district industriel du type Marshall: à savoir, le quartier de la bijouterie à Birmigham (R-U). L'article contribue au débat actuel sur le cycle de vie des regroupements d'entreprises, en présentant une méthodologie pluridisciplinaire qui associe des analyses chronologiques et économqiues aux modèles de la démographie et de l'écologie organisationnelle. On cherche à étudier la structure des taux de naissance et de décès des entreprises, ainsi que la densité du parc d'entreprises à travers des branches d'activités de production afin de mesurer et comprendre le déclin du quartier de la bijouterie pendant les décennies récentes.

Districts industriels du type Marshall / Cycle de vie des regroupements / Théorie écologique

Classement JEL: L23; N80; O14.

Messung des Niedergangs eines Marshallschen Industriedistrikts: das Juwelierviertel von Birmingham 


\section{ABSTRACT}

In diesem Artikel werden die Ergebnisse einer Studie über den Niedergang eines typischen Marshallschen Industriedistrikts vorgestellt, nämlich des Juwelierviertels von Birmingham (GB). Der Artikel versteht sich als Beitrag zur aktuellen Debatte über den Lebenszyklus von Clustern; hierfür präsentieren wir eine multidisziplinäre Methodologie, in der historische und ökonomische Analysen mit demografischen und organisationellen Ökologiemodellen kombiniert werden. Wir untersuchen die Muster der Raten von Firmengründungen und -schließungen sowie die Firmendichte in verschiedenen Branchen der produzierenden Industrie, um den Niedergang des Juwelierviertels in den letzten Jahrzehnten zu messen und zu verstehen.

Key words:

Marshallsche Industriedistrikte

Lebenszyklus von Clustern

Ökologische Theorie

JEL classification: L23, N80 and O14

Medición del declive de un distrito industrial marshalliano: el Jewellery Quarter de Birmingham

Lisa De Propris and Luciana Lazzeretti

\section{ABSTRACT}

En este artículo presentamos los resultados de un estudio sobre el declive de un distrito industrial marshalliano típico: el Jewellery Quarter (barrio de las joyas) en Birmingham (RU). Aquí contribuimos al debate actual sobre el ciclo de vida de las aglomeraciones presentando una metodología multidisciplinaria que combina los análisis históricos y económicos con los modelos demográficos y la ecología organizativa. Lo que pretendemos es analizar los patrones de tasas de nacimientos y mortalidad de las empresas, así como su densidad en todos los sectores de las actividades de producción para medir y entender el declive del Jewellery Quarter en las últimas décadas.

Key words:

Distritos industriales marshallianos

Ciclo de vida de aglomeración y teoría ecológica

JEL classification: L23, N80 and O14

Contacting author: Dr. Lisa De Propris

Birmingham Business School

The University of Birmingham

B15 2TT Birmingham

Tel: 01214146258

E-mail: 1.de_propris@bham.ac.uk 
2

3

4

5

6

7

8

9

10

11

12

13

14

15

16

17

18

19

20

21

22

23

24

25

26

27

28

29

30

31

32

33

34

35

36

37

38

39

40

41

42

43

44

45

46

47

48

49

50

51

52

53

54

55

56

57

58

59

60

Co-author: segreteria.lazzeretti@cce.unifi.it

(a) The authors gratefully acknowledge the financial support of the British Academy for the funding of this research (Grant No. SG-33827). The authors would also like to thank David Bailey, Gabi Dei Ottati, Marco Bellandi, Davide Parrilli and two anonymous referees for useful comments and suggestions. The usual disclaimers apply. 


\section{Introduction}

Over the last two decades, there has been a flourishing debate on the nature, structure and functioning of various forms of clustering and networking. However, contributions on the life cycle of local systems have been much fewer and have mainly tended to look at their emergence, growth, and decline/revival through either qualitative or quantitative analyses (see SwANN et al, 1998; SCOTT, 2000; WOLFE and GERTLER, 2004; MASKELL, 2001 and BRESNAHAN et al, 2001)..

This paper contributes to such a debate with a composite and multi-disciplinary methodology (HEDRON) that combines historical, economic and industrial analyses with demographic and ecological modelling. Demography and population ecology models (HANNAN and FREEMAN, 1989; CARROLL, 1984) were originally used to study variations in the organisational diversity of society and were only later applied to economics. Indeed the novelty of this methodology is to extend the application of firm demography and population ecology models to organisational forms like local production systems and, in particular, to industrial districts, as systems of co-located firms grouped in specific sectors and interlinked by complementarities and synergies. This paper presents an example of cross-fertilisation between industrial organisation and the organisation ecology models (BoOne and VAN WitTEloostulijn, 1995), in fact it refers to a dynamic community approach centred on understanding populations' co-evolution (the latter being one the most interesting streams of the organisation ecology, see AMBURGEY and RAO,1996).

We apply such a methodology to study the decline of the Birmingham Jewellery Quarter in Birmingham (UK) from 1880 to today. The jewellery trade first appeared in Birmingham in the mid-eighteenth century and embedded itself in the vital and vibrant industrial atmosphere that the city had to offer being at the heart of the British Industrial Revolution. The Birmingham Jewellery Quarter grew in size and its organisation of production started to become networked and complex until 1860s when it presented the characteristics of a typical Marshallian industrial district (MARSHALl, 1895 and 1919). ${ }^{1}$ Its fortunes, however, depended on external factors such as fashion, input prices and availability, and technological changes, as well as major historical events like the two World Wars.

In our paper, we seek to explore whether and how the patterns of firms' and sectors' birth and mortality rates explain the decline of the Birmingham Jewellery Quarter as an exemplary case of a typical Marshallian industrial district. In this study we investigate the decline rather than the 'death' of a Marshallian industrial district, since the Quarter is still the home of a concentration of jewellery manufacturing and retailing activities within a tight web of streets. Despite a shrinking of the manufacturing base, it can be argued that the Quarter is transforming itself in an 'urban creative district' with a move towards small batch/customised and more design-intensive productions, 
The paper will proceed as follows. Section 2 will present an historical background of the Birmingham Jewellery Quarter. Section 3 will introduce the current debate on the theories of the life cycle of local production systems and present the composite methodology applied in the final part of the paper. After describing the data collection in Section 4, the findings of the application are detailed in Section 5. Finally, some final remarks will conclude the paper.

\section{Historical background of the Birmingham Jewellery Quarter}

By the mid $19^{\text {th }}$ century, Birmingham had become one of the most industrialised towns in England. The local economy heavily relied on the metal industries -iron, brass, guns, buttons, pins and toys- together with jewellery and some minor industries such as coin minting. In this vibrant context, the Birmingham Jewellery Quarter established itself in a triangle of roads around St. Paul's' Square, to the north of Birmingham; where it still is today (see Figure 1).

Several factors combined to contribute to the development of the jewellery industry in Birmingham, including: (a) the decline of the buckle, toys and button trades provided skilled labour that could easily be employed in the jewellery-making; (b) gold discoveries in California (1848), Colorado (1860), Idaho (1861) and Australia (1860s), silver discoveries in Nevada (mid 1850), and turquoise, amethyst and diamond stone discoveries in Australia and South Africa (1850) made jewellery more affordable and popular; (c) Birmingham was then at the centre of regional and national transport networks -including roads, canals and trains- that provided cheap and easy access to raw materials (e.g. coal) and ensured that commodities could easily and quickly reach consumers across the country and overseas; and finally, (d) local and national demand for jewellery was booming as trade with the colonies made British middle-classes wealthier and personal adornment more fashionable (TIMMINS, 1866).

It was so that by the mid-1800, Birmingham became the centre of Britain jewellery trade and in 1880 the Birmingham Jewellery Quarter was well established and at its peak. DE PROPRIS and LAZZERETTI (2007) provide evidence that at this time it had all the characteristics of a mature Marshallian industrial district (see Section 5.1 for a discussion on this).

World War I damaged the Jewellery Quarter quite badly, although jewellery trade picked up again afterwards. The 1920s and 1930s recessions, and, shortly after, WWII hit the Quarter so deeply that it never really recovered. In the post-war period (1940s and 1950s), the jewellery trade struggled with weak demand due to the post-war purchase $\operatorname{tax}^{2}$, and with labour shortages as other growing industries in Birmingham attracted labour by offering higher salaries. The decision taken decades before to focus on mass production and, to some extent, on the bottom-end of the jewellery market became a serious weakness in the 1970s to 1980s. Tough competition from low cost countries like China, India and Thailand eroded domestic markets; and, at the same time, the export 
of creative and high quality output from Italy flooded the European market, reducing the possibility for Birmingham jewellers to penetrate foreign markets. Overall, the post-War period was characterised by a slow but steady decline, caused by firms' inability to adjust to production changes that were filtering down from technological change, as well as their inability to respond to a new competitive environment. The lack of competitiveness of the manufacturing base in the 1970s (SMITH, 1990) led to its erosion and consequently to a steady employment fall (see Figure 2).

A major change in the composition of activities in the Quarter was the opening of shops in the 1970s. Workshops and small firms started to sell their goods directly to customers (rather than through a networks of salesmen), virtually setting up counters in their front rooms. This paved the way for the Quarter to become not only a manufacturing but also a retailing centre. Indeed, from 1970 to 2005, the proportion of retailing related activities in the Quarter rose from less than 5\% to more than $40 \%$ of the total jewellery activities (DE PROPRIS and WEI, 2007). This move has been accompanied by an effort to distance itself from mass production and cheap jewellery by increasingly aiming at high-value added segments of demand with designer jewellery, and unique and customised pieces. This is reflected in Advantage West Midlands having classified the jewellery industry in the Quarter as a high-value added consumer cluster (see also BIRMINGHAM AND SOlIHUll ECONOMIC ForUM, 2005). A shift from manufacturing to design-intensive, creative jewellery would still mean a re-structuring for the industry but could offer better prospects for its long term sustainability. At the same time, there is serious pressure to open the area to mixed development (office space and residential) in a push to turn the Quarter into the Birmingham's 'Greenwich Village'. 


\section{FIGURE 1 THE BIRMINGHAM JEWELLERY QUARTER}

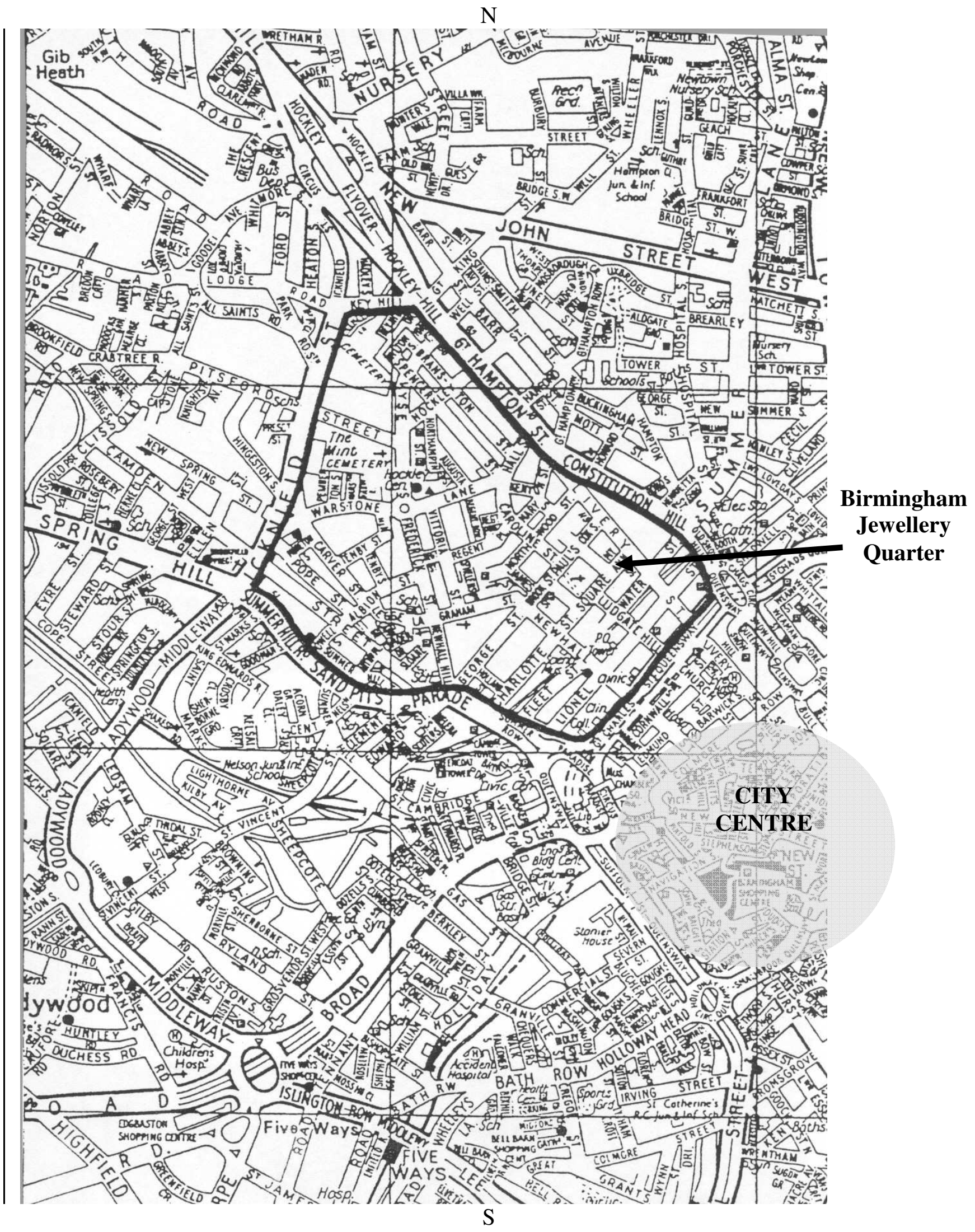

Source: SMITH (1987). 
FIGURE 2 EMPLOYMENT FIGURES IN THE BIRMINGHAM JEWELLERY QUARTER

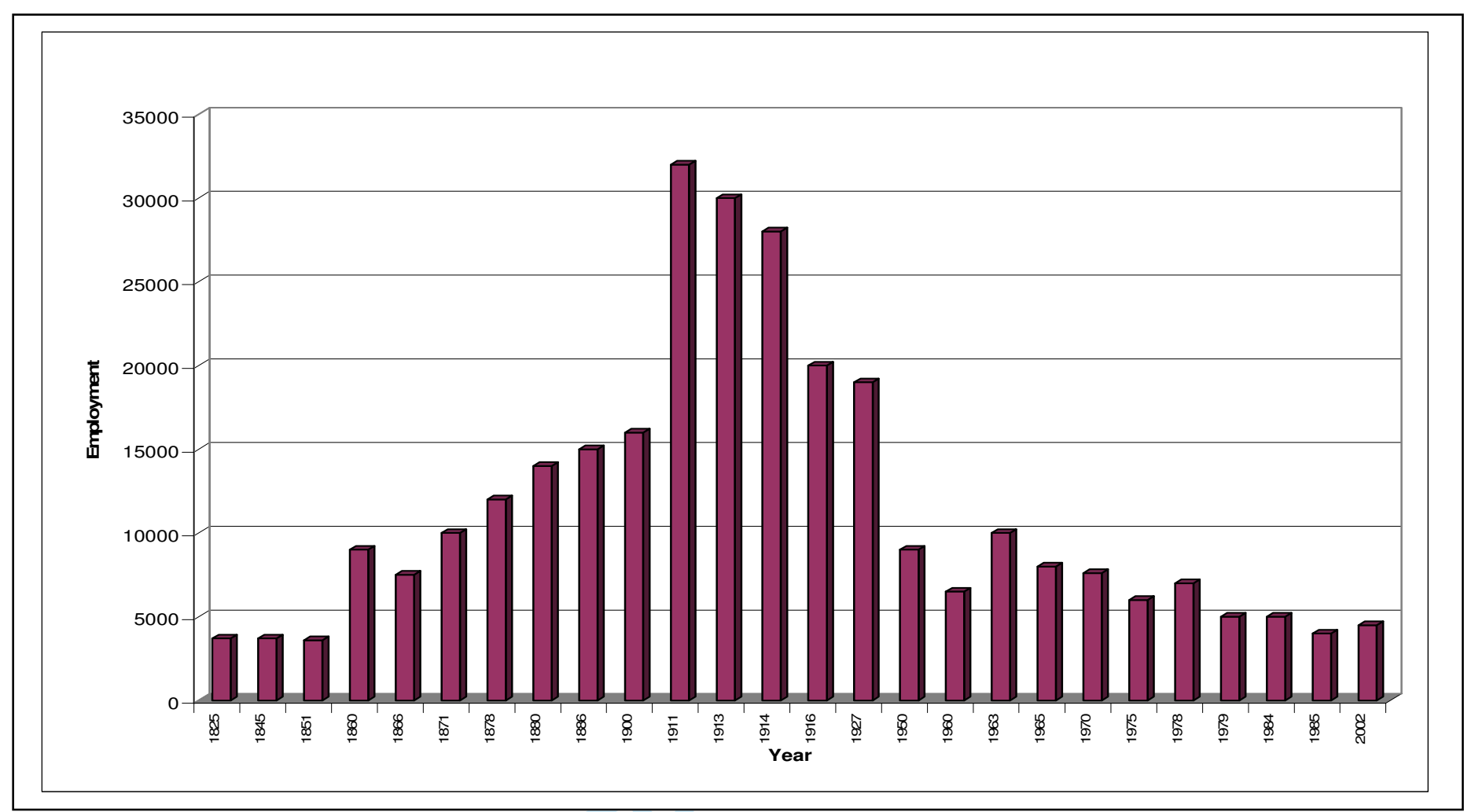

Sources: DE PROPRIS AND LAZZERETTI (2007). 


\section{A Multidisciplinary Methodology to study the Birmingham Jewellery Quarter: HEDRON}

\subsection{Current Debate}

The ever growing literature on local production systems has studied the nature, structure and functioning of various forms of clustering and networking, creating some 'chaos' ${ }^{3}$ in their definitions and labelling. For this reason, it is worth clarifying that we will refer to local production systems to include all forms of complex geographical agglomeration of firms in specialised activities. These include complex systems like industrial districts (BECATTINI 1990, 2004), clusters (PORTER, 1998; SCOTT 1998), innovative milieux (CAMAGNI, 1991), and urban clusters (CUMBERS and MACKINNON, 2004). In particular, in this paper we study a typical 'Marshallian' industrial district as we consider a localised trade in Birmingham already established at the turn at the $20^{\text {th }}$ century.

The debate on the evolution of local production systems is, on the other hand, much thinner. It has included qualitative case studies that have tended to investigate the (endogenous and exogenous) factors and conditions that impact on local systems' evolution; or quantitative studies that have measured the evolution of local systems by evaluating changes in their size and structure (i.e. firms' entry and exit; emergence or disappearance of specific tasks/functions).

In particular, qualitative studies have analysed in detail the life cycle of local production systems as a sequence of stages: emergence, growth, maturity, decline and revival. Those contributions that actually focus on the emergence of local production systems consider firms' location choices, as well as the advantages of agglomeration and proximity (e.g. agglomeration and external economies, and urbanisation externalities) (BAPTISTA, 1998). In contrast, SCOTT (1998)'s market-led theory of 'clustering' stresses the role of demand in determining the structure of the inter-firm division of labour, in that it is market diversification and uncertainty that determine the vertical and horizontal production segmentation internal to the cluster. In other words, demand determines the structure of production within clusters and impacts on their growth and/or decline. SCOTT appreciates that after a certain point co-location can engender agglomeration dis-economies reducing firms' benefits from proximity. In the same line of argument, drawing on a case study on the Silicon Valley cluster, BRESNAHAN et al (2001) argue that clusters' emergence and growth can depend on technology and market opportunities, as well as on increasing returns and external economies. Similarly, GLASMEIER (1994) analyses the evolution of the Hong Kong watch industry as it had to adjust to global market forces and technological shocks. Somewhat differently, MASKELL (2001)'s theory on cluster dynamics pivots around the role of knowledge, whereby the emergence and the growth of clusters can be driven by processes of knowledge creation and accumulation in specific localities. In line with this, BELUSSI (1996) looks at the evolution of Italian 
industrial districts also considering the dynamics of the intra-district division of labour and the processes of knowledge accumulation. The path dependency of knowledge accumulation, however, means that clusters can face phases of stagnation or decline if they become over-specialised, locked into obsolete practices and/or closed to external knowledge flows (BATHELT et al 2002), unless they find ways of coordinating adjustment actions (see DEI OTTATI (2003) for a study of the evolution of the Prato Textile district by means of a Hirschmanian voice-exit approach).

In summary, qualitative studies have analysed the evolution of local production systems by considering their historical development as well as the economic and 'industrial' factors that have influenced them, such as demand, innovation, and knowledge.

On the other hand, quantitative studies have aimed at measuring the structural changes that local production systems experience over time as a reflection of their evolution. In KLEPPER and GRADDY (1990), the emergence of new industries is measured in terms of firm entry and growth. Interestingly, they introduce the idea that the rate of firm entry can explain the formation of a new industry, and suggest that firms' entries peak at a certain point and then stabilise. The main limit of their study is that it considers industries which do not have a geographical dimension. STABER (2001) applies the population ecology model to study the decline of the textile district in BadenWurttemberg, looking, in particular, at how the tension between competition and legitimation processes impact on firms' births and deaths.

More interestingly, given the remit of our paper, SWANN (1998) presents a quantitative model that studies cluster life cycle by looking at new firm formation, incumbent firm growth and crosssector effects. In particular, a life cycle comprises four stages: (a) a cluster emerges when new firms are attracted to the cluster by 'entry attracting' factors, thus contributing to creating a critical mass of firms; (b) a cluster experiences its 'take off' stage when agglomeration economies kick in and incumbent firms grow either in the same sector or in different sectors ('growth promoting' factors); (c) clusters reach maturity when the entry of new firms peaks and the cluster is no longer attractive for new entrants; this is due to congestion especially in mono-sector highly specialised clusters; and finally, (d) clusters reach saturation when no new firms are attracted to it. SWANN (1998) suggests a model where firms' entry and growth are measured and linked to cluster's sector composition, size and life cycle. In so doing, SwANN's model introduces a new methodology to measure and quantify clusters life cycle with more intangible and contextual variables at the core of the qualitative models becoming fixed.

Our contribution is framed in this debate and presents a composite and multidisciplinary methodology that integrates an historical analysis of the evolution of the local system with an analysis of its economic and industrial structure. In addition, in order to measure such evolution we 


\section{Demography and Organisational ecology models}

The organisational ecology theory draws on ecological and evolutionary models and it has emerged as an approach to study long term organisational changes, focusing on organisational diversity and the processes that influence the evolution of organisational forms (SINGH and LUMSDEN, 1990; HANNAN and FREEMAN, 1987, 1989).

Ecological theories contemplate three levels of analysis. Firstly, organisation demography models analyse the evolution of organisations. Secondly, population ecology models assume organisation inertia and look at the evolution of and interactions between populations of organisations, the latter being defined as meaningful groupings of organisations sharing some form of similarity (HANNAN and FREEMAN, 1977). Finally, community ecology models study "the collection of populations that live together in some region" (CARROLL, 1984:72). In particular, population ecology looks at populations' vitality flows (births and deaths) as determined by the 
interactions between co-existing populations, and their impact on the evolution of the organisational community as a whole (BAUM and SingH, 1994; HANNAN and FREEMAN, 1987).

In our application of the organisational ecology model, organisations correspond to firms, populations of organisations to groups of firms, such as sectors or specialisations, ${ }^{4}$ and the community of populations coincides with the collection of inter-related sectors that characterises the district.

There is a wide variety of approaches to organisational evolution (SINGH and LUMSDEN, 1990), but the most appropriate to investigate long-term organisational evolution is the density dependence. Two pioneering empirical studies by HANNAN and FREEMAN $(1987,1988)$ try to explain changes in populations' density (i.e. the number of organisations within a population) and empirically show that there is a relationship between population density and vitality rates (birth and mortality rates), and that therefore population density influences the evolution of the population itself. In other words, the density dependence approach relates the evolution of populations of organisations to their density. In particular, the evolution of populations and communities is driven by two main processes: competition and legitimation. The legitimation process takes place when a population or a community consolidates its position by strenghtening the set of social, political and economic aspects that consistently characterise its organisational form. Legitimation affects the population's vitality rates, so that as birth rates increase more than mortality rates, firm density rises (HANNAN and FREEMAN, 1988). More formally, the legitimation coefficient increases with density at a decreasing rate. On the other hand, the competition process is triggered by the entry of an additional competitor in the population or community so as to induce a process of crowding out due to fighting over a limited set of resource; during the competition process mortality rates increase and the total number of firms decreases. Therefore, the competition coefficient increases with density at an increasing rate.

Both competition and legitimisation processes impact on populations' vitality rates, in that populations' births and mortality rates vary with populations' density rates. In particular, the relationship between the birth rate (or mortality rate) and the density of a population is represented by the rate multiplier coefficient, which is defined as the ratio of the birth rate (or mortality rate) to the rate calculated for the lowest observed population density. In particular, at low density, increasing birth rates have a positive effect on the density due to the legitimation process. When the density of a population peaks, it means that it has reached its carrying capacity. After this point, as competition forces become stronger, the mortality rate increases and the population's density falls. Therefore, HANNAN and FREEMAN $(1987,1988)$ find that the relationship between the density of a population and the multiplier of its founding rate to be non-monotonic and shaped as an inverse $U$ 
(Figure 3)..$^{5}$ In ecomonic terms, a population's carrying capacity reflects the fact that a population (an industry) has reached its critical mass and its growth is peaking.

\section{FIGURE 3: DENSITY DEPENDENCE THEORY: MULTIPLIER OF BIRTH RATE}

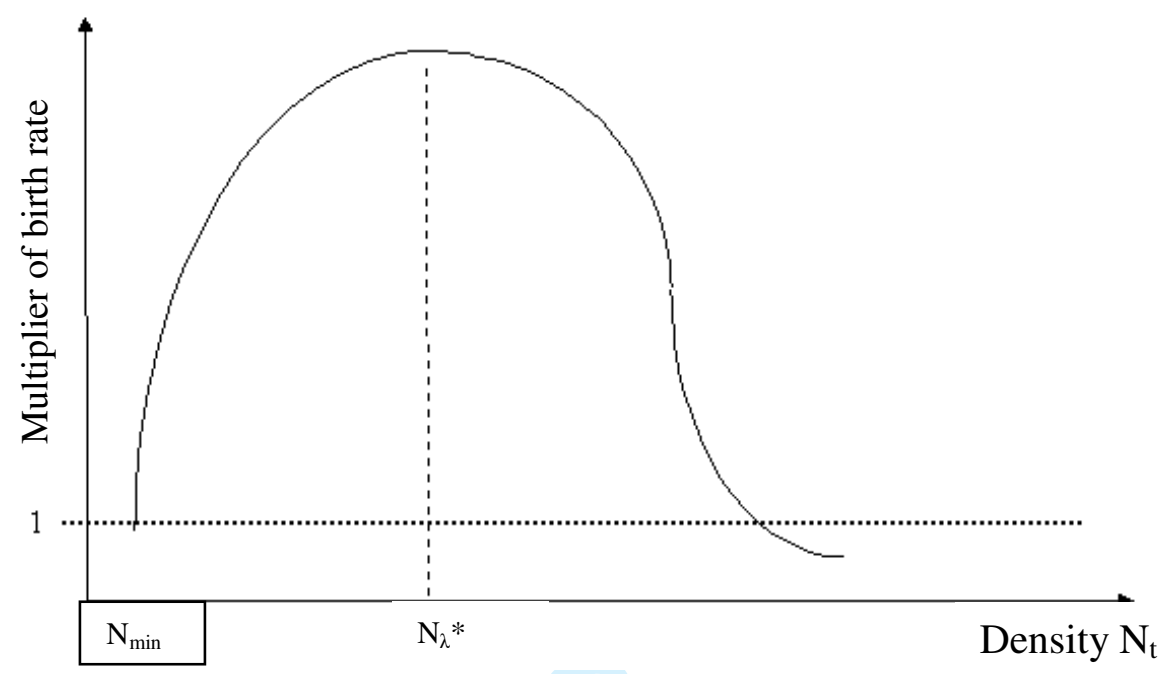

Source: HANNAN and CARROLL (1992)

Sociologists and organisation theorists have mainly applied the organisation ecology theory to the study of industries (including brewing, computer and automotive industries) and trade unions (for a review see for instance, CARROLL and HANNAN, 2004), where industries are considered as populations and firms are the basic organisational forms. Recent contributions have applied the organisation ecology theory to industrial economics. In particular, the organisation demography model has been used to study the evolution of organisational forms such as industries, clusters and industrial districts. More generally, VAN WISSEN (2004) suggests applying the organisation demography model to study the life cycle of industries and firm agglomeration. FORTIS and MAGGIONI (2002) adopt a population ecology model to study the impact of both agglomeration economies and diseconomy in the evolution of some Italian industrial districts. More specifically, for instance, BELUSSI and SCARPEL (2002) analyse the evolutionary pattern of the women's footwear industrial district in Italy (Brenta) by means of an historical and demographical analyses. Similarly, a communtity-based organisation ecological model (density dependence) is applied to the Prato textile industrial district (LAZZERETTI and STORAI, 2003), and the Arezzo jewellery district (LAZZERETTI, 2006) in Italy. With a different focus, GRAHBER (2001) looks at the relevance of competition processes (rivalry) in the transformation of the British advertising industry as an organisational form; likewise, STABER (2001) adopts the organisation ecology theory to study interfirm relations, mortality rates (competition processes) and spatial proximity in a declining industrial district in Baden-Württemberg. Drawing from these, it has emerged that industrial districts can be 
studied as complex organisational forms comprising organisations (firms) and populations (sectors) that taken together constitute a community (the district) of organisational forms.

In this paper, we study the evolution of the Birmingham Jewellery Quarter as a collection of populations related to the jewellery trade in a specific geographical area; in other words we consider a typical MASHALLIAN industrial district as a community of populations. The possibility to study, in particular, industrial districts with the organisation ecology model is endorsed by FOSTER (1993), who argues that MARSHALL (1895) in the Principles was "acutely aware of the socio-economic relevance of organisational analogies drawn from biology" (FOSTER, 1993:987). In fact, selforganisation and the organisation ecology model can describe the growth of systems that are nonlinearly density dependent. Indeed, MARSHALL's law of increasing returns can be seen as mirroring the density dependence of the organisation ecology theorised by HANNAN and FREEMAN.

\section{Data Collection and Unit of Analysis}

We apply the HEDRON methodology to study the decline of the Birmingham Jewellery Quarter. Since 1860, the Quarter has appeared as a localised jewellery industry situated within a tight web of streets just off Birmingham's city centre. ${ }^{6}$ Since its geographical borders have been the object of extensive research in the past (SMITH, 1989, WISE, 1950 and GILBERT, 1972) and this has generated a broad consensus on its location, we decided to collect data on jewellery and jewelleryrelated firms in the 45 streets located within such borders.

We have collated a database of firms from 1880 to 1973 . Due to data constraints, we had to start our analysis at a time when the BJQ was already established. The database contains records of 11,400 firms that have existed for any period of time over the 90 years covered by the data: 513 firms were still operating in 1973.

The database has been collated by transferring data and information from three historical Birmingham Directories (Kelly's Directory of Birmingham, Hulley's Directory of Birmingham and Houghton's Directory of Birmingham) into a spreadsheet. ${ }^{7}$

The database comprises a set of information to trace the life and death of firms. For each firm we have recorded the name, address, production activity and ownership status. ${ }^{8}$ As we are analysing the production activities of artisans, craftsmen and workshops, the activity or specialisation associated with the firm and the name of the owner (or craftsman) are both crucially important to identify the firm itself.

Reliance on the above Directories presented some problems due to the degree of imprecision in the actual data collection at the time. For instance, in our study we are interested in tracing firms' births and deaths, and for this it is crucially important to ascertain whether the disappearance of a 
firm from the directory for one year corresponded to an actual death or just an overlook. To offset this level of imprecision, we considered a firm as surviving if it was missing for one year, but reappeared the year after. In the same way, the wording used to define production activities tended to vary, so we decided to classify production activities into broader categories which were also more manageable from a statistical point of view (for instance, a 'gold wedding ring maker' was classified as 'gold ring maker' so that we kept the information about the material -that is very important for the jewellery industry- and the degree of specialisation). Even with this 'rounding' we identified more than 350 specialisations. ${ }^{9}$

Since we are analysing the production activities of artisans, craftsmen and workshops, both the activity/specialisation of the firm and the name of the owner (or craftsman) are crucially important to identify the firm itself. A firm's founding is defined as the year when it first appeared in the directory (new name-new activity-new address) or the year it first appeared with a new name or a new activity (same address-same activity-new name or same address-same name-new activity). With this, we are able to compute for each year the firms' birth rate within the Quarter. A firm's death is defined as the year the firm disappeared from the directory. Given the lack of further information, we assumed that if a firm disappeared from the Jewellery Quarter, it was, for the purpose of our study, dead. The reason for this is that we are interested in analysing the evolution of the production activities within the area as an organisational form, i.e. a community of populations. A firm's survival corresponds to the presence of the same firm (same address-same name-same activity or same name-same activity-change of address still within the Quarter) year after year.

\section{The Decline of a Marshallian Industrial District: the Birmingham Jewellery Quarter}

In this section, we present the results of the application of the HEDRON methodology to the BJQ, by carrying out historical, economic, industrial, demographic and ecological analyses of its evolution from 1880 to today.

\subsection{The Historical Analysis}

Jewellery craftsmanship in Birmingham can be recorded as early as 1308 (MASON, 1998), but the first agglomeration of jewellers emerged around 1750-70 in the Newhall and the Colmore Estates. In the eighteenth century, the Jewellery Quarter went through its pre-district stage thanks to the skilled labour made available from the declining buckle, toys and button trades. Important landmarks in the establishment of the Quarter were the 1766 opening of Soho Manufactory at Soho by Matthew Boulton as the first large factory in Birmingham; in 1773, the establishment of the Birmingham Assay Office for silver goods only and in 1794, the setting up of the Birmingham 
Mint. ${ }^{10}$ Until 1800, the Birmingham Jewellery Quarter was an emerging agglomeration of jewellers with production activities not yet clearly identified and integrated (a pre-district stage).

Gold and silver discoveries, as well as technological change contributed to its growth throughout the 1800 s, so that, by 1860 , the Jewellery Quarter was a fully formed Marshallian industrial district. Not only was it a district at the time of Marshall's writing (MARSHALL, 1895), but its production organisation and social context were intertwined and structured like MARSHALL'S industrial districts. The Jewellery Quarter was, in fact, an agglomeration of small firms specialised in the jewellery industry; production was segmented but perfectly integrated along production stages. The combination of an external division of labour with specialisation generated external economies that resulted in innovation and learning. In addition, production activities were imbued in a thick social environment given by the presence of a living population, strong personal and social relationships and the existence of political, social and production related institutions. ${ }^{11}$

From 1880 to 1920 the Quarter experienced a consistent period of expansion, which was abruptly interrupted by WWI when most of the jewellers turned to manufacturing munitions or went into the army. In this period, although the jewellery trade remained mostly craft-based, some manufacturing activities such as electroplating and stamping forced firms to grow in size due to the increasing use of mechanisation associated with mass production and standardisation (HoPKINS, 2001), as well as the introduction of gas-powered machinery (ALLEN, 1929). These larger factories included the Argent Centre, Bates \& Fallows and Elkington, which for instance in 1887 had about 2000 employees. Over this period, production activities in the Birmingham Jewellery Quarter started also to diversify as new branches of trade were introduced such as silver decorated objects, ornamental medals, cups, sport related articles, shields, as well as jewellery decorated with diamond and other precious stones. The expansion and the multiplication of jewellery activities coincided with the search for workshop premises. So, if until then there was an overlap between living and working communities, by the early twentieth century space was reallocated from residential to trading purposes, so that the Quarter became mainly a business area. 


\section{FIGURE 4 HISTORICAL AND ECONOMIC ANALYSIS}

\begin{tabular}{|c|c|c|}
\hline Period & District Structure & Technological and Market Shocks \\
\hline $\begin{array}{l}\text { 1750-70 } \\
\text { Pre-District } \\
\text { Birth }\end{array}$ & $\begin{array}{l}\text { First agglomeration of artisan and hand-craft jewellers } \\
\text { following the decline of the buckle \& toy trades providing } \\
\text { skilled labour }\end{array}$ & Output market: Local \\
\hline $\begin{array}{l}\mathbf{1 7 7 0 - 1 8 0 0} \\
\text { Pre-District } \\
\text { Embryonic } \\
\text { stage }\end{array}$ & $\begin{array}{l}\text {-Institutional set-up (Assay Office and B'ham Mint) } \\
\text {-Geographical expansion } \\
\text {-Creation of production segmentation and specialisation }\end{array}$ & Output market: Local \\
\hline $\begin{array}{l}\text { 1800-60 } \\
\text { District } \\
\text { Growth }\end{array}$ & $\begin{array}{l}\text {-Max geographical expansion of the BJQ } \\
\text {-Completion of the process of production segmentation and } \\
\text { integration } \\
\text {-Consolidation of legal framework (gold hallmarking) }\end{array}$ & $\begin{array}{l}\text { 1840-60 } \\
\text { Input market shocks: } \\
\text {-gold discoveries in California, Colorado, Idaho and Australia } \\
\text {-silver discoveries in Nevada } \\
\text {-stone discoveries in Australia and South Africa } \\
\text { Innovation shocks: } \\
\text { electroplating, electro-nickel plating and electro-galvanising }\end{array}$ \\
\hline $\begin{array}{l}\mathbf{1 8 6 0 - 1 9 1 5} \\
\text { District } \\
\text { Maturity }\end{array}$ & $\begin{array}{l}\text {-Co-existence of small jewellery craftsmen and large } \\
\text { electroplating and stamping firms } \\
\text {-Diversification of production activities with new branches of } \\
\text { trade } \\
\text {-Consolidation of institutional setting (British Jewellery \& } \\
\text { Silversmith Assoc. and jewellery schools) } \\
\text {-Residential population driven out by demand for industrial } \\
\text { premises } \\
\text { There were two short depressions (1875-78 and 1880-86) in a } \\
\text { period of stable growth. The number of businesses in the BJQ } \\
\text { peak in } 1914 \text { followed by stagnation during WW1 }\end{array}$ & $\begin{array}{l}\text { Input market shocks: } \\
\text {-gold discoveries in South Africa } \\
\text { Output market: } \\
\text {-domestic markets, trade with colonies and competition from } \\
\text { American and Germans jewellers } \\
\text {-new markets in Latin America } \\
\text {-introduction of mail order } \\
\text {-development of retailing within the BJQ } \\
\text { Innovation shocks: } \\
\text { introduction of gas supply to burners; stamping machinery and } \\
\text { magneto-electro machinery }\end{array}$ \\
\hline $\begin{array}{c}\mathbf{1 9 1 5}-45 \\
\text { District } \\
\text { Recession }\end{array}$ & $\begin{array}{l}\text { WWI and WWII drove labour out of the trade and diverted trade } \\
\text { to ammunition production. } \\
\text { Employment increased again after WWI but the } 1929 \text { crisis } \\
\text { stalled the recovery }\end{array}$ & Drop in demand \\
\hline $\begin{array}{c}\text { 1950-60 } \\
\text { Contraction }\end{array}$ & $\begin{array}{l}\text { Employment keeps falling due to: } \\
\text { - post-war purchase tax } \\
\text { - labour shortages as labour was attracted by other growing } \\
\text { industries in Birmingham }\end{array}$ & Demand picks up again \\
\hline $\begin{array}{c}\text { 1970-90 } \\
\text { Stagnation }\end{array}$ & $\begin{array}{l}\text { - Manufacturing activities survive } \\
\text { - Employment stable but in slight decline } \\
\text { - Opening of shops and retailing activities }\end{array}$ & $\begin{array}{l}\text { - Penetration of low cost imports coming from China, India \& } \\
\text { Thailand } \\
\text { - tough competition from Italy at the top end of the market }\end{array}$ \\
\hline $\begin{array}{c}\text { Today } \\
\text { Revival? }\end{array}$ & \multicolumn{2}{|c|}{$\begin{array}{l}\text { Focus on designer-makers and marketing activities to re-position the jewellery industry as a creative industry (with policy } \\
\text { support) } \\
\text { - } \quad \text { More and better space for retailing and marketing } \\
\text { - } \quad \text { Stronger presence at international trade fairs/aggressive export strategy } \\
\text { - } \quad \text { Regeneration of the area as a mixed-use quarter (office, flats and catering) } \\
\text { - } \\
\text { Re-positioning of the BJQ as part of the Birmingham City Centre }\end{array}$} \\
\hline
\end{tabular}

Source: this figure draws on DE PROPRIS and LAZZERETTI (2007).

Between 1880 and 1910 a process of institutional thickening also took place: in 1887, the Birmingham Jewellers and Silversmiths Association was set up; in 1880 the School of Art was opened, followed in 1890 by the Jewellery School, and in 1901 the Vittoria School of Jewellery and Silversmiths, finally in 1908-09 the University of Birmingham began to organise a course on jewellery management. ${ }^{12}$

In 1911 employment reached its maximum with more than 30,000 workers. WWI stalled its growth. After the war the jewellery trade resumed its activities, but the 1920s and 1930s recessions, and, shortly after, WWII hit the Quarter so badly that it never really recovered.

The historical analysis would seem to suggest that by 1920 the Quarter was a mature and dynamic industrial district, aware of being a complex and efficient production system whereby 
shared benefits could be reaped by collective actions as the process of institutional thickening around the industry demonstrates.

\subsection{The Economic and Industrial Analyses}

Drawing on the information gathered in our database, we find that the Birmingham Jewellery Quarter has been an agglomeration of firms, artisans and workshops specialised in jewellery related activities. We find 357 task specialisations overall ${ }^{13}$, each corresponding to a stage in the production process and to a firm/craftsman. SMITH (1989) refers to the external division of labour in the Quarter as firms being "effectively linked by a human conveyor belt which carried small but valuable articles from one workshop to another around nearby streets and within factories" (p.96). LAZZERETTI and STORAI (2003) argue that specialisation variety is evidence of the maturity for a local production system; therefore, the highly segmented division of labour especially for the manufacturing and hand-craft tasks is proof of the Jewellery Quarter's maturity at the time (for an historical comment, see GLEDHILL, 1988).

In particular, from the historical records gathered in our database, we are able to reconstruct the production chain or filière of the jewellery trade that we summarise in Figure 5 below. The main production stages are: tools; raw materials; jewellery manufacturing (including goldsmithing, silversmithing, electroplating, gilting and non-jewellery manufacturing); first, second and third processing stages; and sales and retail. Some categories contain several specialisations. The arrows help identify the direction of the production links between stages.

Tool manufacturing and the supply of raw materials feed into the first processing stage, whose output is then passed onto jewellery manufacturing. Jewellery manufacturing is also linked to production services and the second processing stage. The former supplies manufacturers with non-jewellery services such as boxes and design, while the latter provides extremely specialised hand skills that jewellery manufacturers contract out. The final stage of production before sales and retail is the third processing stage which includes skills that are at the very end of the jewellery production process, such as polishing and engraving. 


\section{FIGURE 5 PRODUCTION FILIÈRE}

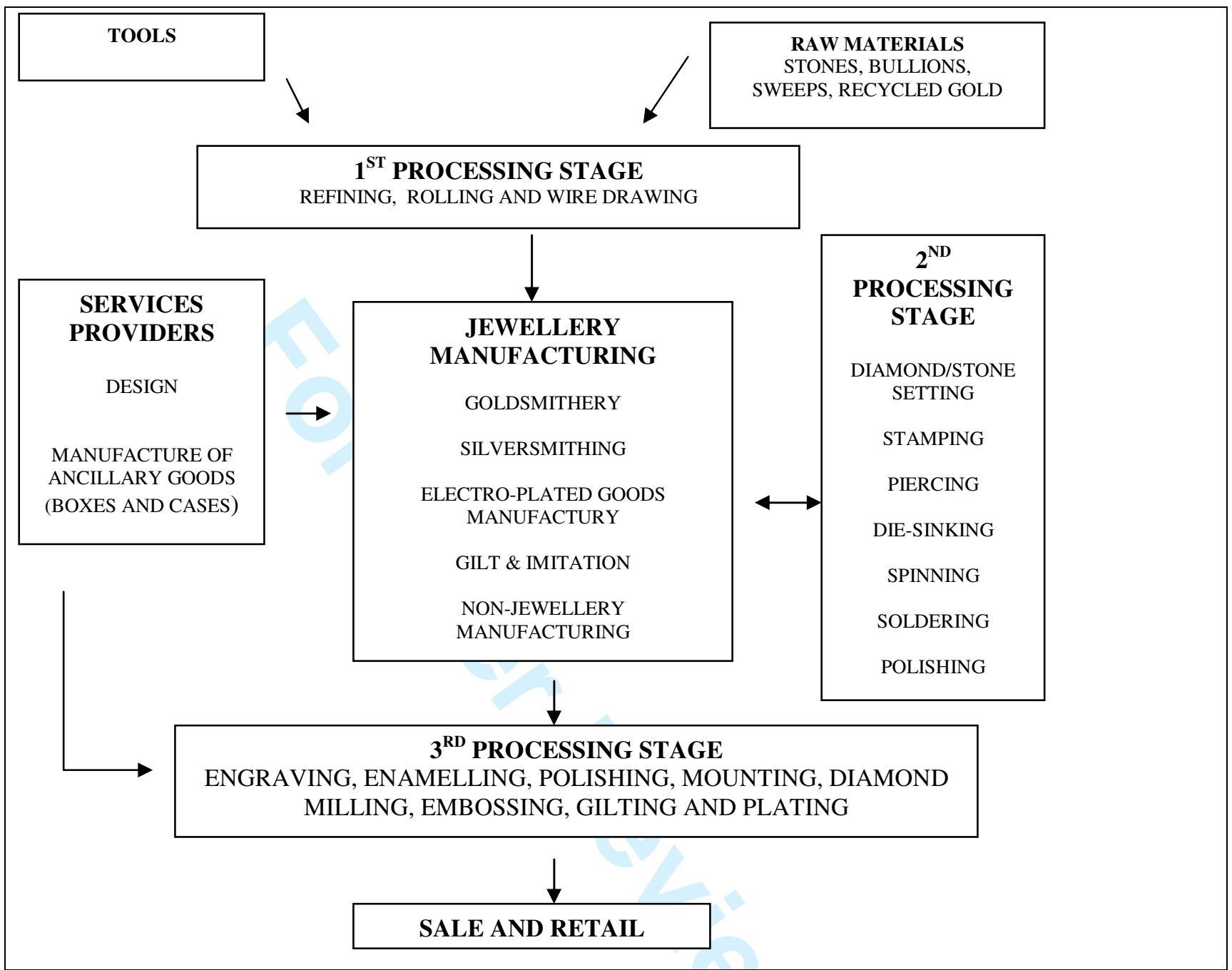

Source: this figure draws on DE PROPRIS and LAZZERETTI (2007).

In order to apply the organisational ecology model, we have translated the 357 specialisations into populations. The evident difficulty in tracing their individual evolution has been overcome by the definition of multi-populations as meaningful groups of populations. In particular, we identify five multi-populations on the basis of the production stages just described: (a) Raw materials and tools; (b) Jewellery manufacturing; (c) Processing manufacturing; (d) Service providers; and (e) Sales and retailing (see Figure 6 below).

The largest multi-population is 'processing manufacturing', followed by 'jewellery manufacturing' (as it will be shown later these are actually the core populations that have survived throughout the evolution of the Jewellery Quarter). 


\section{FIGURE 6 MULTI-POPULATIONS}

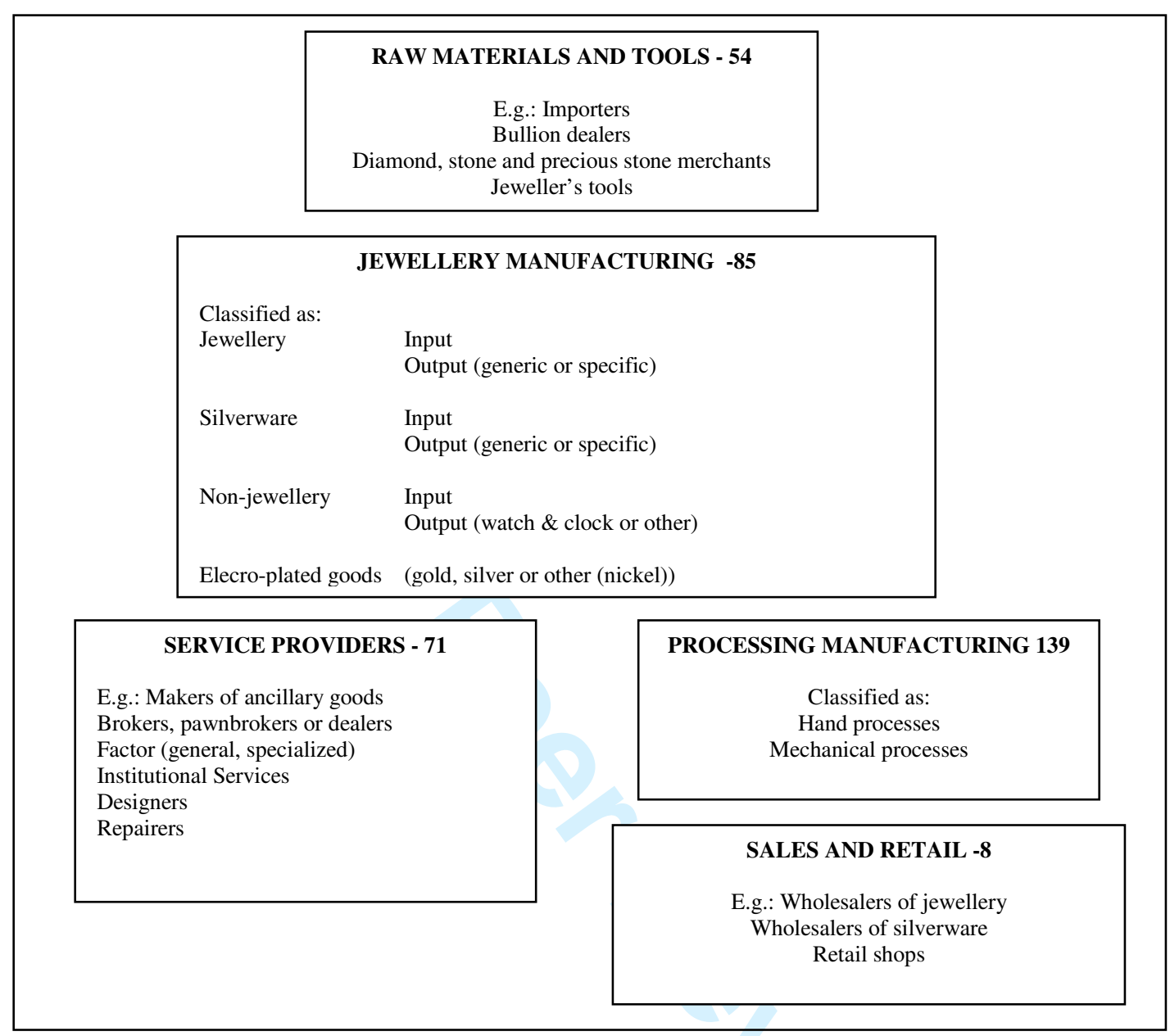

Note: The numbers in the boxes for each multi-population correspond to the number of populations, i.e. specialisations/sectors, in each of them.

Source: Authors' calculation drawing on the database.

\subsection{The Demographical Analysis}

The main steps of a demographic analysis are the calculation of firms' births and deaths, and firm total density first at the community level (in our case at the level of the industrial district, the BJQ), and then at the multi-population level. This enables us to measure the evolution of the district in terms of its structure and size. This is the first step in a rigorous analysis of the district's life cycle and it therefore integrates and expands on the historical and economic analysis already presented.

The Birmingham Jewellery Quarter's firm density measures the number of firms $\left(\mathrm{N}_{\mathrm{t}}\right)$ actually operating in the Quarter each year. It is calculated as the sum of firm density $\left(\mathrm{N}_{\mathrm{t}}\right)$ at $t-1$ and the difference between firms' births $\left(\mathrm{B}_{\mathrm{t}}\right)$ and deaths $\left(\mathrm{D}_{\mathrm{t}}\right)$ at time $t$, as described below $N_{t}=N_{t-1}+\left(B_{t}-D_{t}\right)$, with $\mathrm{t}=1881,1882 \ldots 1973$. 


\section{FIGURE 7 FIRMS’ BIRTHS AND DEATHS IN THE BJQ AS A COMMUNITY (1880-1973) \\ FIGURE 7 FIRMS' BIRTHS AND DEATHS IN THE BJQ AS A COMMUNITY (1880-1973)}

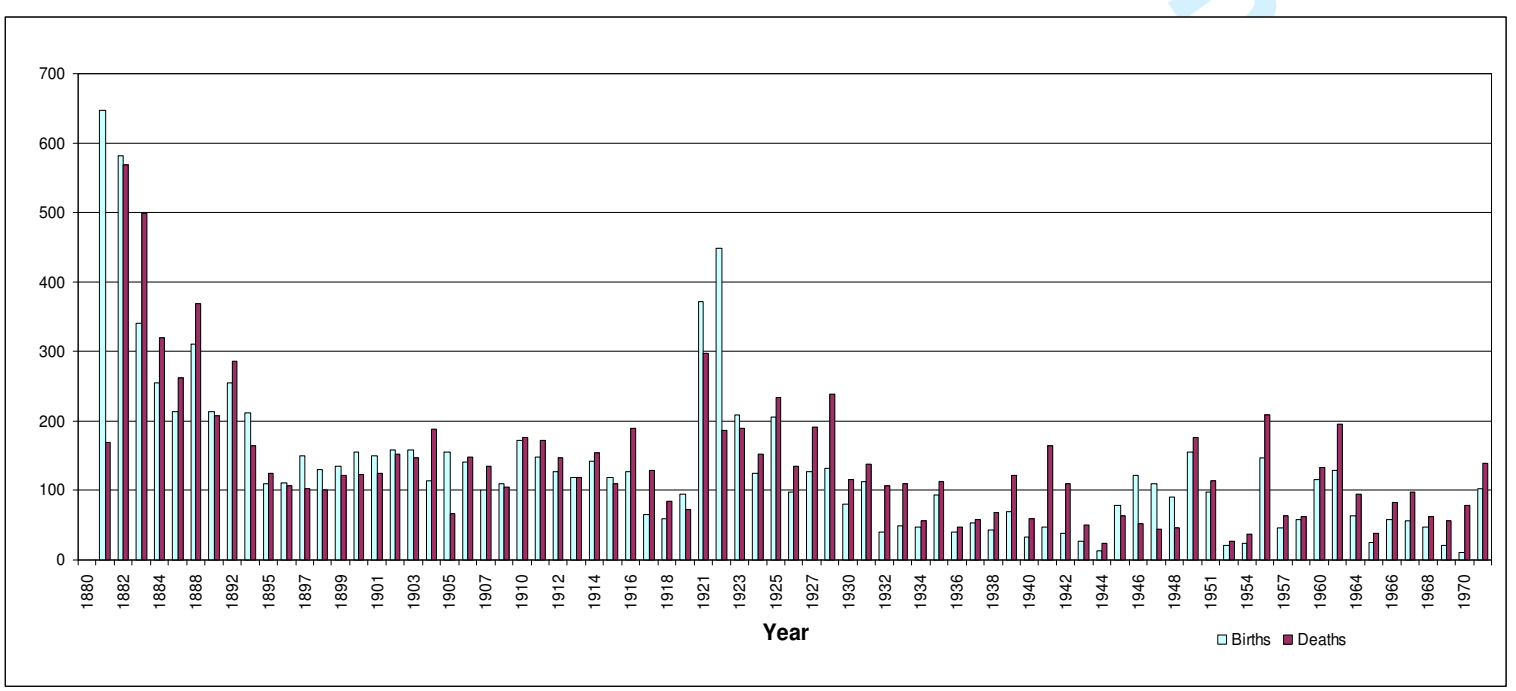
directories). In particular, between 1880 and 1973, we registered 11,400 new firms ${ }^{14}$ and more than 10,500 deceased firms (Figure 7).

As expected, firms' birth rates are very high in 1880-81 as this is the beginning of our database. Nevertheless, the high birth rate in the early 1880 s is in line with the historical analysis that found that the Jewellery Quarter was well established and at its zenith. From 1890 to World War I the internal dynamics of the district show signs of 'vitality', as the fluctuations of the birth and death rates show. As deaths outnumber births, firm density drops between 1915 and 1919 (WWI). In fact, firms' deaths peak in 1915 without a corresponding number of births. This period is followed by a period of great recovery as firm density increases by 20 per cent. Indeed, in 1923 the number of firms peaks with 1691 firms. Between the two World Wars the recovery is dampened by the 1929 crisis, as firm density decreases over time and, at the same time, fluctuations in deaths and births peter out. After WWI, the district moved from its consolidation phase to a phase of decline that the limited recovery in the 1920s could not stop, as shown by the steady drop in firm density. WWII again shakes the district and firm density plummets. The small recovery in the period 194548 (in this period firm births outnumber firm deaths) does not take the district back to the size it had in the 1920s and the continuous decline of firm density thereafter validates the hypothesis that it was in continuous 'free fall'. In 1973 there are only 494 firms against 1650 in 1881 (see Figure 8). density in 1884, and then add to it the difference between firms' births and deaths in 1885 (Figure $8)$.

In order to compute firms' births and deaths, we calculate how many firms were born and how many firms deceased each year (in other words, firms that have appeared and disappeared from the 西

\section{(1)}


Source: Authors' calculation.

FIGURE 8 FIRM DENSITY IN THE BJQ AS A COMMUNITY (1880-1973)

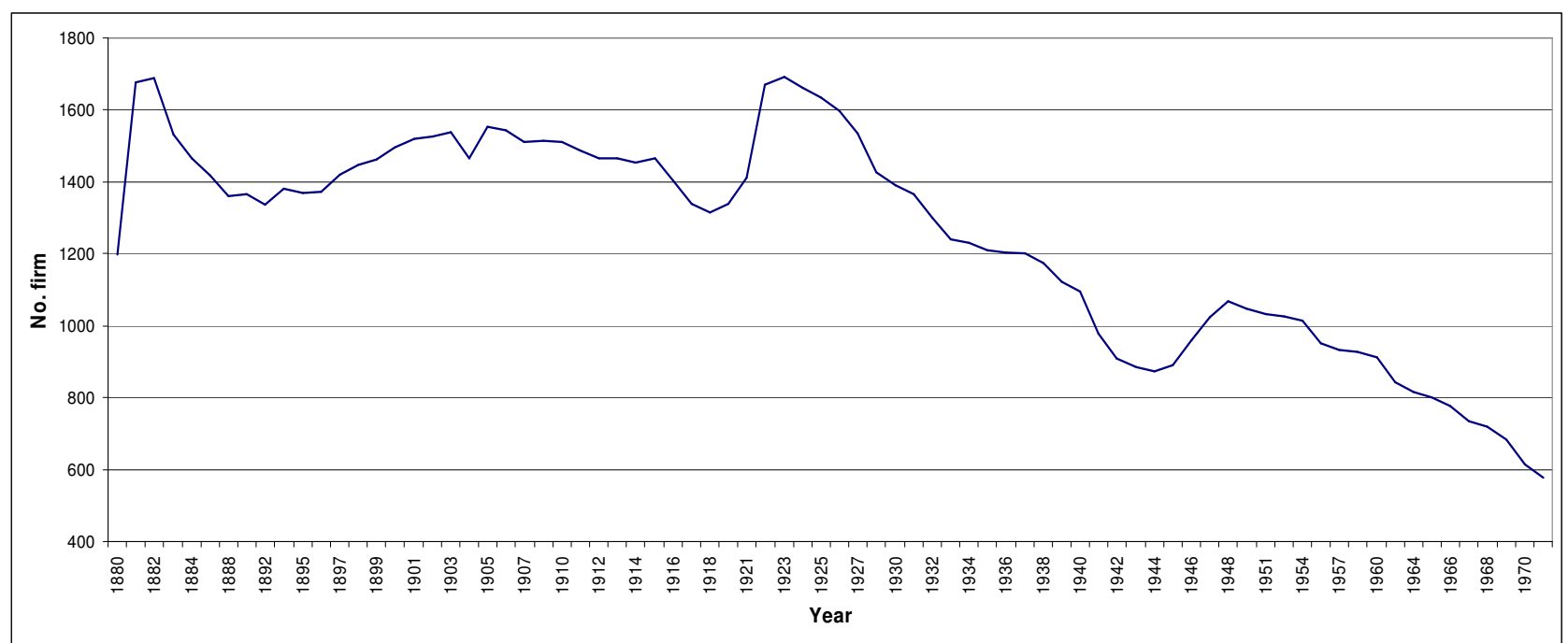

Source: De Propris and Lazzeretti (2007).

For the multi-population analysis, we compute firms' births and deaths for each of these five multi-populations and draw density functions. In order to calculate the density of each multipopulation, we use the following formula:

$N_{t j}=N_{(t-1) j}+\left(B_{t j}-D_{t j}\right)$,

where $t=$ years and $j=1, \ldots, 5$ multi-populations

Figure 9 below summarises the evolution of the shares of the five multi-populations, providing a picture of the composition of activities. It is worth noticing that the two major groups over the entire period remain 'process manufacturing' and 'jewellery manufacturing'. It must be noted that these include all the key manufacturing stages of the external division of labour through which semi-finished and finished goods pass. This is evidence that throughout the period of study the Quarter has remained heavily manufacturing and handcraft-based as a traditional Marshallian industrial district. The other three groups look small in size, especially the 'sales and retail' and 'raw materials and tools'. This is not a surprise given that the historical analysis has shown that, for instance, shops started opening only in the 1970s. 


\section{FIGURE 10 FIRM DENSITY OF THE RAW MATERIALS AND TOOLS MULTI-POPULATION}

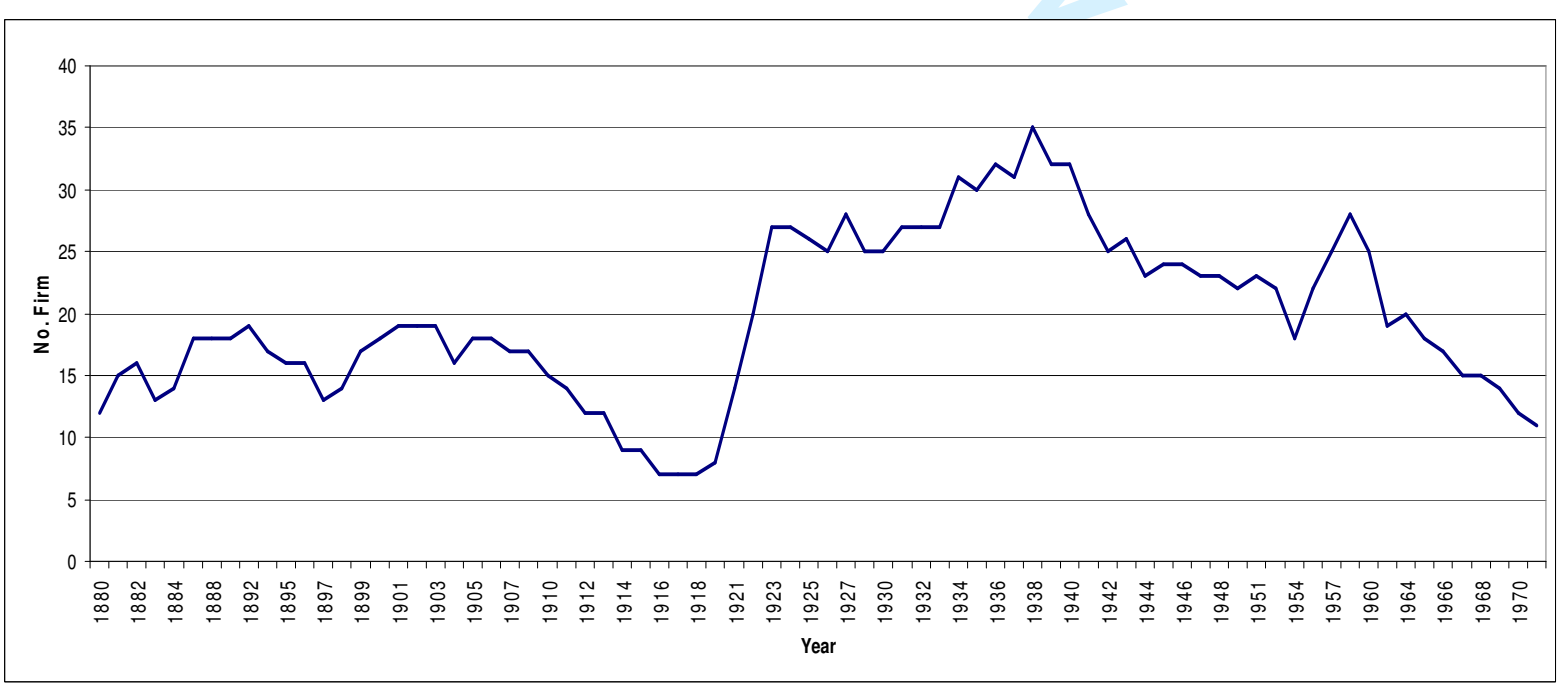

Source: Authors' calculation. 
FIGURE 11 FIRM DENSITY OF THE JEWELLERY MANUFACTURING MULTI-POPULATION

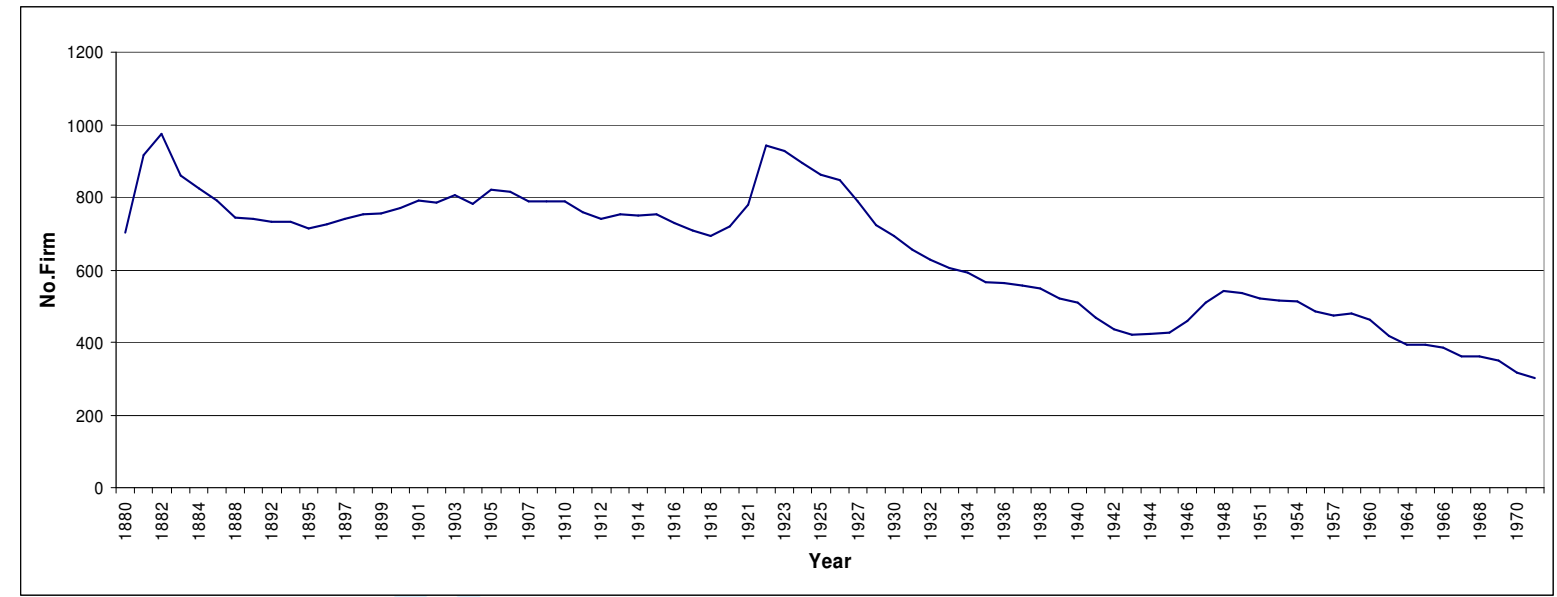

Source: Authors' calculation.

FIGURE 12 FIRM DENSITY OF THE SERVICE PROVIDERS MULTI-POPULATION

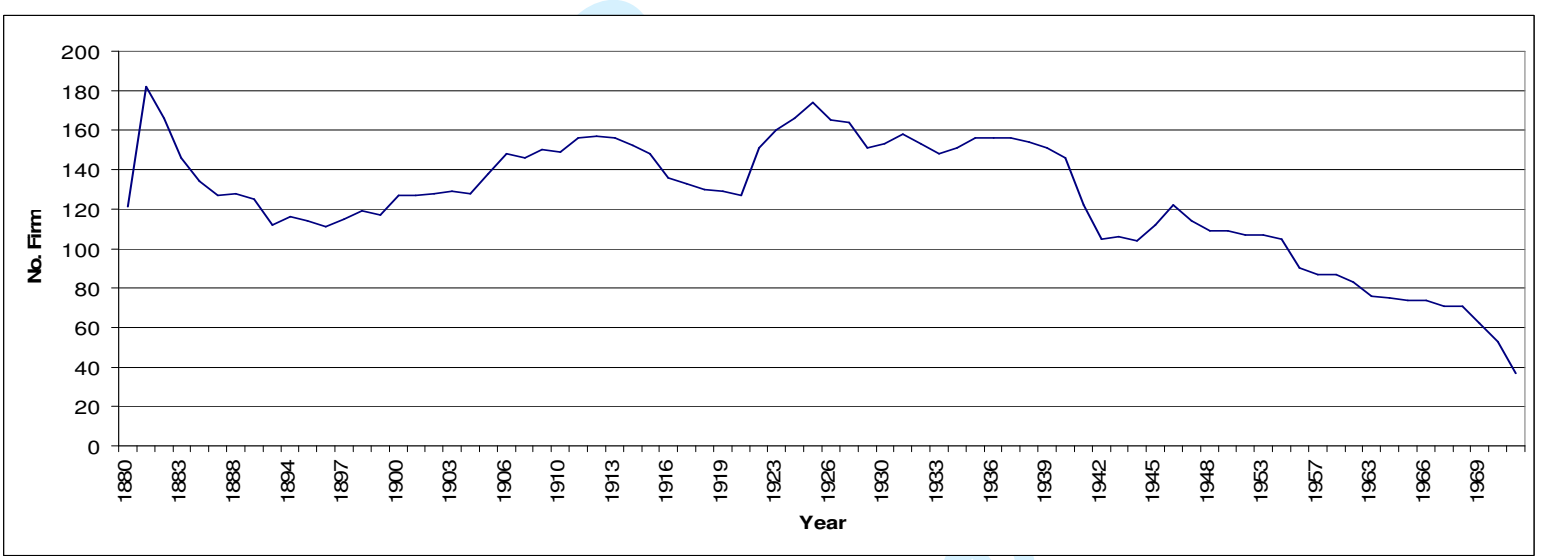

Source: Authors' calculation.

FIGURE 13 FIRM DENSITY OF THE PROCESSING MANUFACTURING MULTI-POPULATION

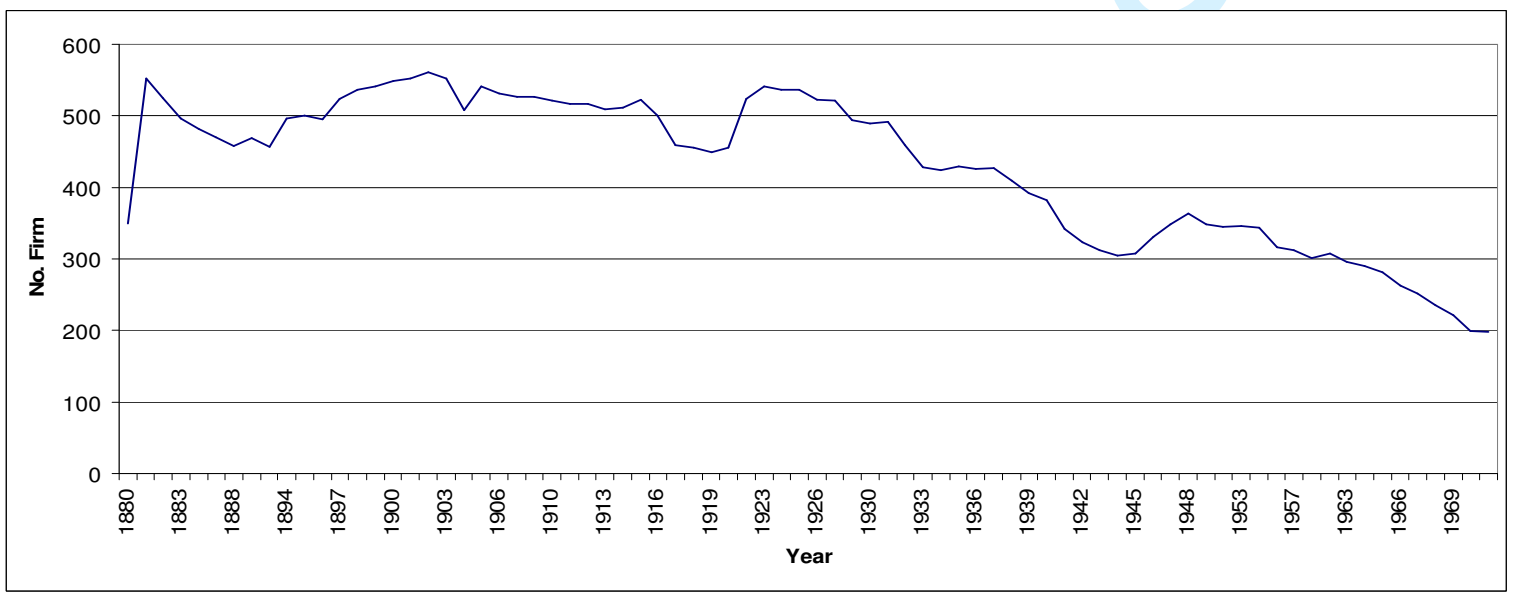

Source: Authors' calculation. 


\subsection{The Ecological Analysis}

In Section 5.3, we find that the firm density curve for the Birmingham Jewellery Quarter is non-monotonic and inversely U-shaped (Figure 8). Given that this is a necessary condition for the ecological analysis to be applied, it is possible to proceed to the ecological analysis.

The contribution of ecological modelling is to measure the life cycle of the industrial district by means of a density dependence model. A methodology to study social or economic events is the event history analysis. In particular, event history analysis uses different methodologies according to the kind of event being studied. When analysing firm foundings, the most frequently models are those that consider recurring events as outcomes of stochastic processes. As a consequence, the cumulative number of events observed up to a certain point in time $t$ is assumed to be a nondecreasing stochastic process (ALLISON, 1988).

Firm births are considered discrete events, ${ }^{15}$ therefore the stochastic process - and the underlying distribution of probability - must be discrete. In particular, Poisson processes are used (HANNAN and FreEMAN, 1989; LOMI and LeVIE, 1995). A Poisson process assumes that the rate of arrival is independent from the history of previous arrivals and from the current state of the system. Among other things, this assumption implies that the order of events does not affect the arrival rate. If the rate at which new organisations are born in a population follows a Poisson process, then the rate is a time-independent constant. Since we know the number of births per year, the model of the founding rate is based on a simple Poisson model: ${ }^{16}$

$$
\lambda(t)=\exp \left(\theta_{1} N_{t}+\theta_{2} N_{t}^{2}+\delta_{1} B_{t-1}+\delta_{2} \mathrm{D}_{t}\right) \exp \left(\Sigma \phi_{i} X_{i t}\right)
$$


where $\lambda(t)$ is the multiplier of the founding rate, the two orders of density are represented by $N_{t}$ and $N_{t}^{2} ; X_{i t}$ is the vector of covariates, and the vector of parameters $\phi_{i}$ correspond to the period variables. ${ }^{17}$ Finally, we introduce in the model, firms' births at $t-1\left(\mathrm{~B}_{t-1}\right)$ and firms' deaths $\left(\mathrm{D}_{t}\right)$ in order to ascertain how they influence the density rate over the period. ${ }^{18}$

\section{The Model}

Figure 15 reports the maximum likelihood estimates of the Poisson model of densitydependence for firms' foundings in the Jewellery Quarter. All parameters are significant and in line with the hypothesis, except for model (1) where the parameter of the second order effects $\left(\right.$ density $\left.^{\wedge} 2\right)$ is positive.

Model (1) estimates first (density) and second (density ${ }^{\wedge}$ ) order effects of density. Model (2) includes also lagged births (birth $(t-1)$ ). Model (3) analyses also the second order effect of lagged births (births $\left.(t-1)^{\wedge} 2\right)$. Model (4) also considers lagged deaths (deaths $(t-1)$ ). Model (5) contains all the previous variables and it adds also period effects, allowing the study of different probabilities of births with respect to the period 1956-70 which is omitted in the model.

According to our hypothesis, the first order effect of density (density) is significant and positive in all models and the second order effect (density^2) is significant and negative in all models except for Model (1): this confirms the inversely $\mathrm{U}$ shape of the birth rate (Figure 1). The first order parameter associated with lagged births $\left(\right.$ birth $\left._{(t-1)}\right)$ is positive and the second order parameter (births $\left.{ }_{(t-1)}\right)^{2}$ ) is negative. Lagged births are found, therefore, also to be inversely Ushaped, since the effect of the competition process prevails on the legittimation process in determining firms' births. The parameters of firm deaths (deaths $\left.{ }_{(t-1)}\right)$ are significant and negative as expected. 


\section{FIGURE 15 POISSON REGRESSION MODEL ESTIMATIONS OF BIRTHS IN THE BJQ,} 1881-1973

\begin{tabular}{|c|c|c|c|c|c|}
\hline & Model 1 & Model 2 & Model 3 & Model 4 & Model 5 \\
\hline \multirow[t]{2}{*}{ Intercept } & $4,2075^{* * *}$ & $1,9546 * * *$ & $0,2.5968 * * *$ & $2,3498 * * *$ & $\overline{0}-4534 * * *$ \\
\hline & $(0,1166)$ & $(0,1429)$ & $(0,1461)$ & $(0,1519)$ & $(0,3867)$ \\
\hline \multirow[t]{2}{*}{ Density } & $0,001 * * *$ & $0,0038 * * *$ & $0,0021 * * *$ & $0,0026 * * *$ & $0.0072 * * *$ \\
\hline & $(0,0002)$ & $(0,0003)$ & $(0,003)$ & $(0,0003)$ & $(0.0006)$ \\
\hline \multirow[t]{2}{*}{ Density $^{\wedge} 2$} & $0,0012 * * *$ & $\begin{array}{l}- \\
0,0014 * * *\end{array}$ & $-0,0007 * * *$ & $\begin{array}{l}0,0010 * * * \\
\end{array}$ & $\begin{array}{l}- \\
0.0025^{*} * *\end{array}$ \\
\hline & $(0,0001)$ & $(0,0001)$ & $(0,0001)$ & $(0000,1)$ & $(0.0002)$ \\
\hline \multirow[t]{2}{*}{ Births (t-1) } & & $0,0031 * * *$ & $0,0063 * * *$ & $0,0079 * * *$ & $0.0049 * * *$ \\
\hline & 2 & $(0,0001)$ & $(0,0003)$ & $(0,0003)$ & $(0.0004)$ \\
\hline \multirow[t]{2}{*}{ Births $(\mathrm{t}-1)^{\wedge} 2$} & & & $-0,0050 * * *$ & $0,0064 * * *$ & $0.0035 * * *$ \\
\hline & 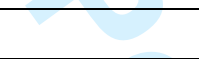 & & $(0,0004)$ & $(0,0004)$ & $(0.0005)$ \\
\hline \multirow[t]{3}{*}{ Deaths (t-1) } & & & & $0,0010 * * *$ & $0.0011 * * *$ \\
\hline & & & & $(0,0001)$ & $(0.0001)$ \\
\hline & & 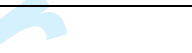 & & & \\
\hline \multirow[t]{2}{*}{ Period 1881-95 } & & & & & $\begin{array}{l}- \\
0.3703 * * *\end{array}$ \\
\hline & & & & & $(0.0437)$ \\
\hline \multirow[t]{2}{*}{ Period 1896-1910 } & & & & & $\begin{array}{l}- \\
0.2276 * * *\end{array}$ \\
\hline & & & & & $(0.0369)$ \\
\hline \multirow[t]{2}{*}{ Period 1911-25 } & & & & & $0.5166 * * *$ \\
\hline & & & & & $(0.0459)$ \\
\hline \multirow[t]{2}{*}{ Period 1926-40 } & & & $\sqrt{20}$ & & $0.1947 * * *$ \\
\hline & & & & & $(0.0693)$ \\
\hline \multirow[t]{3}{*}{ Period 1941-55 } & & & & & $0.8075^{*}$ \\
\hline & & & & 2 & $(0.1087)$ \\
\hline & & & & 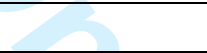 & \\
\hline DF & 87 & 85 & 84 & 83 & 78 \\
\hline Log likelihood & 46.892 & 46.898 & 46.985 & 47.013 & 47140 \\
\hline
\end{tabular}

Standard error in brackets. *: $\mathrm{p}<0,0001 ;{ }^{*}: \mathrm{p}<0,001, *^{*}: \mathrm{p}<0,01 ;$ Period Variable Omitted P 1956-1973

The analysis of firms' births has focused on two aspects. Firstly, the maximum value of the multiplier of the entry rate $\left(\lambda^{*}\right)$ shows the maximum level of the relative strength of legitimation and competition processes. A high value of $\lambda^{*}$ implies that the density effect on legitimation is relatively strong compared to that of competition. As evidence of this, we report the multiplier of the rate calculated for its maximum and minimum value of density observed: $\lambda\left(N_{\mathrm{MAX}}\right)$ and $\lambda\left(N_{\mathrm{MIN}}\right)$. 
Figure 16 presents the main quantitative implications of the effects of density on founding rates. The first two columns show the range of density of models (4) and (5) over the period 18811973. The minimum density $\left(\mathrm{N}_{\mathrm{MIN}}\right)$ is 523 in 1973, while the maximum density $\left(\mathrm{N}_{\mathrm{MAX}}\right)$ is 1689 in 1881 as the density curve is over the whole period decreasing. Column 3 reports the estimates for the multiplier of the founding rate when it reaches its maximum value $\left(\lambda^{*}\right)$, while column 4 and 5 contains the estimates for the multiplier computed at the maximum $\lambda\left(N_{\mathrm{MAX}}\right)$ and minimum $\lambda\left(N_{\mathrm{MIN}}\right)$ observed population density. Column 6 shows the year when the density is at its maximum and column 7 shows the year when density is at its minimum. Column 8 and 9 estimate the effect of density dependence legitimation and competition processes.

\section{FIGURE 16 QUANTITATIVE IMPLICATIONS OF ESTIMATES OF DENSITY- DEPENDENCE IN FOUNDING RATES}

\begin{tabular}{lccccccccc}
\hline Model & $\mathrm{N}_{\text {MIN }}$ & $\mathrm{N}_{\mathrm{MAX}}$ & $\lambda^{*}$ & $\lambda\left(\mathrm{N}_{\mathrm{MIN}}\right)$ & $\lambda\left(\mathrm{N}_{\mathrm{MAX}}\right)$ & $\mathrm{T}\left(\mathrm{N}_{\mathrm{MAX}}\right)$ & $\mathrm{T}\left(\mathrm{N}_{\mathrm{MIN}}\right)$ & $\begin{array}{l}\text { Legittimation } \\
\text { effect }\end{array}$ & $\begin{array}{l}\text { Competition } \\
\text { effect }\end{array}$ \\
\hline Model (4) & 523 & 1689 & $\approx 1$ & $\approx 1$ & $\approx 0$ & 1881 & 1971 & $+0.26 \%$ & $-0.1 \%$ \\
Model (5) & 523 & 1689 & $\approx 1$ & $\approx 1$ & $\approx 0$ & 1881 & 1971 & $+0.72 \%$ & $-0.25 \%$
\end{tabular}

Source: Authors' calculation.

Figure 16 shows the multiplier of the founding rates of models (4) and (5) for the BJQ. In both models, the organisational founding rate reaches its maximum when population density is close to 1 and, from there, it decreases because of null legitimation processes ( $\lambda^{*}$ is around 1). At the maximum density in 1881 (1689 firms), the founding rate tends to 0 ( $\lambda\left(N_{\mathrm{MAX}}\right)$ ) because of competition processes. In both models the hypotheses about density parameters are confirmed, but the second order effects dominate the first order effects over the entire range of density, therefore the multiplier of the founding rate curve is an inversely U-shaped, as it declines immediately as the competition process prevails on the legitimation one. 


\section{FIGURE 17 MULTIPLIER OF THE FOUNDING RATE ${ }^{19}$ FOR THE BJQ (MODEL 4 AND MODEL 5)}

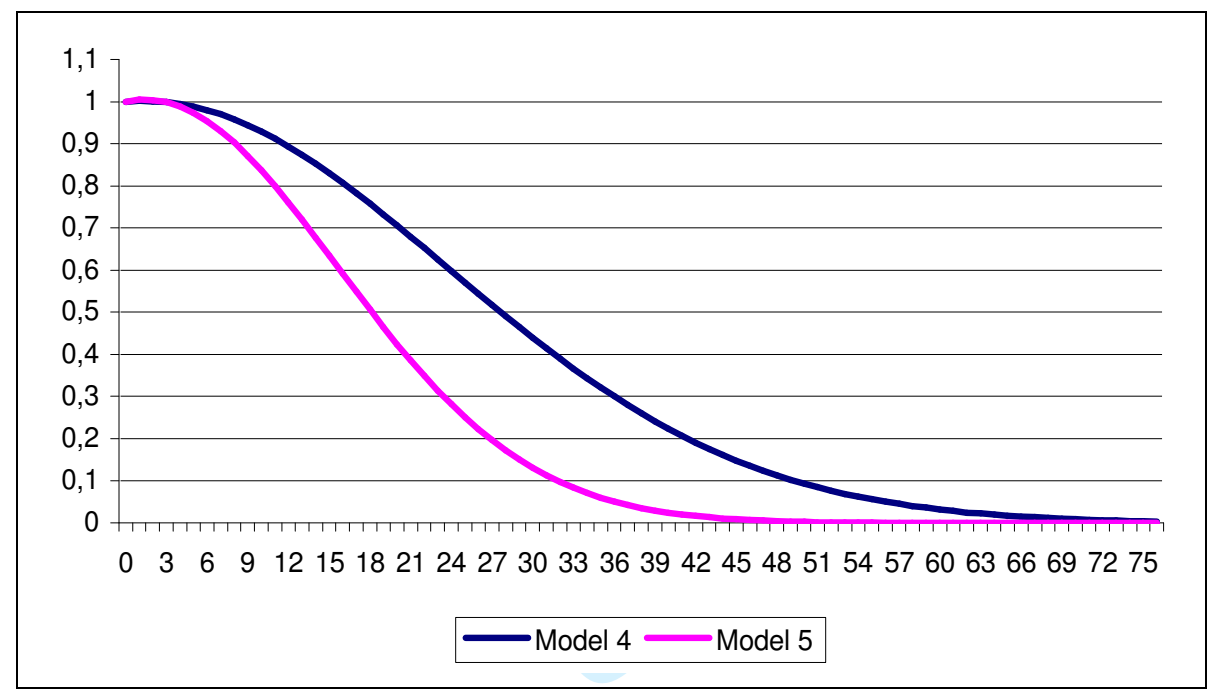

Source: Authors' calculation.

To summarise, Figure 17 delivers a very important result for the study of the decline of the Jewellery Quarter, in that is it shows that at the staring point of our analysis (it is worth remembering that the start date was decided on the basis of data availability) it had passed its growth phase; it had reached its zenith and maturity, and was starting to decline. According to the density dependence approach, this means that in 1880 the Quarter, as an organisational form (as a community of populations), was probably at its carrying capacity, since competition processes started to replace legitimation processes. In other words, as firms' births increase the community total density decreases.

\section{Conclusion: From Industrial District to Urban Creative District}

In this paper we have presented the findings of a study on the decline of the Birmingham Jewellery Quarter as a Marshallian industrial district. The first key result of the paper is to provide some qualitative and quantitative evidence that the Quarter peaked in its life cycle at the turn of the $20^{\text {th }}$ century, followed by a period of stagnation and more recent contraction.

A second novelty is to present a composite and multidisciplinary methodology that contributes to the debate on the life cycle of local production system by integrating historical and economic analyses with demographic and ecological modelling (HEDRON methodology). This methodological novelty has relevant implications for studies on industrial districts -and of local production systems more generally- as dynamic organisational forms. In fact, not only does it acknowledge that external and internal events shape the historical context that frames the evolutions 
of such system, but it appreciates how such events affect the organisation of systems in terms of activities and specialisations and, ultimately impact on their overall evolution. In particular, quantitative evidence of the decline of the Birmingham Jewellery Quarter has been provided by means of business demography and organisational ecology.

Drawing on a unique database with more than 11,400 firm recorded, we have been able to describe the organisation of production in the jewellery industry; to calculate firms' births and deaths, and firms' density curves by production activities and for the entire Quarter; and finally to run the ecological model.

Our findings are that in demography terms, firm density in the Jewellery Quarter peaked by the early 1900s and the multiplier of the founding rate decreased thereafter; while, in ecological terms, it can be concluded that the Quarter had by then reached its point of maximum expansion the so called carrying capacity. It was unfortunate for us that data was available only after 1880, because the stages of emergence and growth had taken place before.

Since the 1970s, the Jewellery Quarter has experienced a process of slow decline which is evident from employment figures (Figure 2). On the demand side, this is due to a weakening of its domestic market and an inability to penetrate foreign markets. On the supply side, there has been a break down of the internal division of labour as some specialisations have disappeared, retailing has expanded, and finally, imports of cheaper finished or unfinished goods have replaced internal production and have flooded the domestic market. Nevertheless, the Jewellery Quarter is still a concentration of jewellery and jewellery-related manufacturing and service firms.

Today there is a smaller but still significant manufacturing base, whilst retailing has been steadily expanding. If in 1973 there were less that 30 firms in sales and retails (corresponding to less than 5\% of the total), a census of activities in the Quarter in 2005 (DE PROPRIS and WEI, 2007) has found that there are 124 firms in retailing related activities, corresponding to more than $40 \%$ of activities overall. The move to increase retailing activities has been accompanied by an effort to target high-value added segments of demand with designers' jewellery, and unique and customised pieces. This is reflected in local policy agencies increasingly recognising the creative content of jewellery making and the added value that this can bring to the industry; for instance, Advantage West Midlands has classified the jewellery industry in the Quarter as a high-value added consumer cluster (see also Birmingham AND Solihull ECONOMIC ForUM, 2005; HALl and Welch, 2005) and recognised that design can be central to business success. The shift from manufacturing to design-intensive, creative jewellery would still coincide with some re-structuring in the industry but could also offer more hope its long term sustainability. We would, therefore, suggest that the decline of the Jewellery Quarter as a Marshallian industrial district is not coinciding with its death, 
rather with its reshaping and possible renaissance as an urban creative district, whereby differences in the nature of activities are coupled with continuity in the form of socio-production organisation. 


\section{REFERENCE}

Allison P.D. (1988) Event History Analysis: Regression for Longitudinal Event Data, Beverly Hills, Sage University.

Allen G.C. A. (1929) The Industrial Development of Birmingham and the Black Country, Allen and Unwin, London.

Amburgey T.L. and Rao H. (1996) Organization Ecology: Past, Present and future, Academy of Management Journal,Vol.39, n.5,1265-1286.

BAPTISTA R. (1998) Clusters, Innovation and Growth: A Survey of the Literature, In SwANN G.M., PreVezer M. and Stout D. (Eds) The Dynamics of Industrial Clustering, OUP, Oxford.

BAthelt H.M., MAlberg A. and MAsKell P. (2002) Clusters and Knowledge: Local Buzz, Global Pipelines and the Process of Knowledge Creation. DRUID Working Paper No. 02-12, Copenhagen.

BAUM J. and SINGH J (1994) Evolutionary dynamic of organizations, N.Y., Oxford University Press.

Bechttini G. (1990) The Marshallian Industrial District as a Socio-Economic Notion, in Pyke F., BeCATtini G. and Sengenberger W. (1990) Industrial Districts and Inter-firm Cooperation in Italy, Geneva, International Institute for Labour Studies.

BeCAtTini G. (2004) Industrial Districts. A New Approach to Industrial Change, Edward Elgar, Cheltenham.

BELussi F. (1996) Local Systems, Industrial Districts and Institutional Networks: Towards a New Evolutionary Paradigm of Industrial Economics, European Planning Studies, Vol. 4, No.1, 522.

BELUSSI F. and SCARPEL M. (2002) L'evoluzione recente del distretto della Riviera del Brenta: un approccio organizzativo, Economia e politica industriale, n. 115, pp. 43-70.

Birmingham \& SOlihull ECONOMIC ForUm (2005) Annual Report. Birmingham Chamber of Commerce

Boone C. and VAn WiTteloostuiJn (1995), Industrial Organization and Organizational Ecology: the Potentials for Cross-fertilisation, Organization Studies,16/2,pp 265-298.

Bresnahan T., Gambardella A. and SaXenian A. (2001) 'Old Economy' Inputs for 'New Economy' Outcomes: Cluster Formation in the New Silicon Valley, Industrial and Corporate Change, Vol. 10, No. 4, 835-860.

CAMAgni R.P. (ed.) (1991) Innovation Networks. Spatial Perspective, Belhaven, London.

CARroll G.R. (1984) Organizational ecology, Annual review of sociology, No 10, pp. 71-93.

Carroll G. R. and Hannan M. T. (2004) The Demography of Corporations and Industries, Princeton University Press, Princeton.

ChERry G.E. (1994) Birmingham. A Study in Geography, History and Planning, Chichester, Wiley.

CUMBERS A. and MACKINNON D. (2004) Introduction: Clusters in Urban and Regional Development, Urban Studies, Vol. 41, No. 5/6.

De Propris L. and LAZZeretti L. (2007) The Birmingham Jewellery Quarter: A Marshallian Industrial District, European Planning Studies, vol. 15, no. 10, pp.1-31. 
De Propris L. and WeI P. (2007) Governance and Competitiveness in the Birmingham Jewellery Cluster, Urban Studies. vol 44, No.12.

De Propris L., Lazzeretti L., Storai D. (2004) Impannatori and Business Angels: Two Models of Informal Capital Provision, International Journal of Urban and Regional Research, Vol. 28, No. 4, 839-854.

Dei Ottati G. (2003) Exit, Voice and the Evolution of Industrial Districts: The Case of the Postworld War II Economic Development of Prato, Cambridge Journal of Economics, Vol. 27, 501-522.

DelacroiX J. and CARroll G. R. (1983), Organizational Foudings: An Ecological Study of the newspaper Industries of Argentina and Ireland, Administrative Science Quarterly, vol. 28, nr. 2 .

FOSTER J. (1993) Economics and the Self-organisational Approach: Alfred Marshall Revisited? The Economic Journal, Vol. 103, No. 419, 975-991.

Fortis M. and Maggioni M. (2002) Competitive and Synergic Behaviours in the Development of Industrial Clusters: Ecological Modelling and Empirical Evidence, CURZIO A.Q. and FORTIS M. (Eds.) Complexity and Industrial Clusters, Physica-Verlag, Heidelberg, 123-165.

GILBERT C. (1972) The Evolution of an Urban Craft: The Gold, Silver and Allied trades of the West Midlands, PhD Thesis, The University of Birmingham.

GLEDHILl A. (1988) Birmingham Jewellery Quarter, Brewin Books, Reddich.

GLASMEIER A.K. (1994) Flexibility and Adjustment: The Hong Kong Watch Industry and Global Change, Growth and Change. Vol 25, 223-246

GRABHER G (2001) Ecologies of Creativity: the Village, the Group, and the Heterarchic Organisation of the British Advertising Industry. Environment and Planning vol. 33 pp351374

Hall C. and Welch I. (2005) Study of Designer Makers Operating in Birmingham's Jewellery Quarter, Archway

Hannan M.T. and Carroll G.R. (1992) Dynamics of Organizational Populations: Density, Legitimation and Competition, New York, OUP.

HANnAn M.T. and FreEman J. (1977) The Population Ecology of Organisations, American Journal of Sociology, No. 82, 929-964.

HANNAN M.T. and FREEMAN J. (1987) The Ecology of Organisational Founding: American Labour Unions 1936-1985, American Journal of Sociology, Vol. 94, No. 4, 910-943.

HANNAN M.T. and FREEMAN J. (1988) The Ecology of Organisational Mortality: American Labour Unions, 1836-1985, American Journal of Sociology, Vol. 94, No. 1, 25-52.

HANNAN M.T. and FREEMAN J. (1989) Organisational Ecology, Harvard University Press, Cambridge.

Hassall M. (1993) The Growth and Development of the Jewellery Quarter, mimeo, The University of Birmingham.

Hopkins E. (1998) The Rise of the Manufacturing Town. Birmingham and the Industrial Revolution, Sutton, Stroud.

Hopkins E. (2001) Birmingham. The Making of the Second City 1850-1939, Tempus, Strout.

Houghton’s Directory (1882) Street Directory, Birmingham, Houghton \& Co.

HulleY’s Directory (1881) Street Directory, London, Kelly \& Co. 
KeLly's DiRECTORY (1880, 1883-1974) Street Directory, London, Kelly \& Co.

KLEPPER S. and GRADDY E. (1990) The Evolution of New Industries and the Determinants of Market Structure, The Rand Journal of Economics, Vol. 21, No.1, 27-44.

LAZZERETTI L. and Storai D. (2003) An ecology based interpretation of district complexity: the Prato district evolution from 1946-1993, in Belussi F., GotTARDI G. and Rullani E. (Eds.) The Technological evolution of Industrial Districts, Kluwer, Dordrecht, 409-435.

LAZZERetTi L., (2006) Density Dependent Dynamics in Arezzo Jewellery District (1947-2001): Focus on Foundings, European Planning Studies, vol 14(4) 431-458

Lomi A. and LeVIE J. (1995) Density Dependence and Spatial Duality in the Foundings Rates of Danish Commercial Banks 1846-1989, WP Academy of Management Meeting, Vancouver No. 6-9, 1-28.

Marshall A. (1895) Principles of Economics, Third Edition, Vol. 1, London, Macmillan and Co.

MARSHALl A. (1919) Industry and Trade, London, Macmillan.

MARTIN R. and P. SUnLEY (2003) Deconstructing clusters: chaotic concept or policy panacea?, Journal of Economic Geography, vol. 3

MASKELl P. (2001) Towards a Knowledge-based Theory of the Geographic Cluster, Industrial and Corporate Change, Vol. 10, no. 4, 921-943.

MASON S. (1998) Jewellery Making in Birmingham, 1750-1995, Phillimore, London.

Pollard J. S. (2004) From Industrial District to Urban Village? Manufacturing, Money and Consumption in Birmingham's Jewellery Quarter, Urban Studies, Vol. 41, No. 1, 173-193.

PORTER (1998) Clusters and the New Economics of Competition, Harvard Business Review, Nov/Dec, 77-90.

Roche J.C. (1927) The History, Development and Organisation of the Birmingham Jewellery and Allied Trades, Birmingham, Dennison Watch Case Co. Ltd..

Sargant Florence P. (1948) Investment, Location and Size of Plant, Cambridge, Cambridge University Press.

ScotT A.J. (1998) Regions and the World Economy: The Coming Shape of Global Production, Competition and Political Order, OUP, Oxford.

ScOTT A.J. (2000) Regions and the World Economy, Oxford, Oxford University Press.

SINGH J. and LUMSDEN C. (1990) Theory and research in organizational ecology, Annual Review of Sociology, vol. 16, pp. 161-195.

SMITH B.M.D. (1987) Report of an Interview-based Survey in the Birmingham Jewellery Quarter relating to the Jewellery Industry, Centre for Urban and Regional Studies, The University of Birmingham.

SMith B.M.D. (1989) The Birmingham Jewellery Quarter, a Civic Problem that Has Become an Opportunity in the 1980s, in TILSON B. (Ed.) Made in Birmingham. Design and Industry 1889-1989. Studley, Brewin Books.

SMith B.M.D. (1990) Economic Regeneration Strategies in Birmingham, England, Illustrated by a Case Study of the Jewellery Quarter in Birmingham. The University of Birmingham. Mimeo.

StABer U. (2001) Spatial Proximity and Firm Survival in a Declining Industrial District: The case of Knitwear Firms in Baden Württemberg, Regional Studies, Vol. 35 No. 4, 329-341. 


\section{NOTES}

${ }^{1}$ De Propris and LAZZERETTI (2007).

${ }^{2}$ In 1947, taxes on luxury items like jewellery increased to $145 \%$, remained as high as $75 \%$ in the 1950s, to be abolished only in 1973 when VAT was introduced (MASON, 1998).

${ }^{3}$ MARTIN and SUNLEY (2003).

${ }^{4}$ Organisational populations could correspond, for instance, to sectors as defined by the standard SIC classification. For the BJQ we could not rely on such a structured classification of economic activities; we had therefore to group service and production activities according to their role along the value chain.

${ }^{5}$ If the density curve is not non-monotonic, some descriptive statistics (univariate, bi-variate, multivariate, spatial, etc.) can be carried out in order to support the qualitative study of the phenomenon.

${ }^{6}$ For more details on the BJQ location, see CHERRY (1994), HOPKINS (1998) and DE PROPRIS and LAZZERETTI (2007).

${ }^{7}$ Data was not available for the following years: 1885, 1887, 1889, 1891, 1893, 1909, 1920, 1928, 1949, 1951, 1955, 1959, 1961 and 1962. When computing the density, we have filled these gaps by estimating proxies; it is standard procedure to calculate proxy values for each firm as the average between density of the year before and the year after the gap. We apply the following formula:

Density $_{z}=\frac{\text { density }_{z-1}+\text { density }_{z+1}}{2} \quad$ with $z=$ missing year.

${ }^{8}$ There is little information about how data was collected, but it is well accepted that the most likely way was for publishers to have had people who physically walked around the streets of Birmingham and stopped at every shop or household asking for names and types of economic activity/trade or looking at name plates. In this way, every year they gathered data and information that was then published in a directory. Each directory classified economic activities by street, name and trade.

${ }^{9}$ See De Propris and LAZZERETTI (2007).

${ }^{10}$ For the history of the Birmingham Assay Office, see RYLAND (1866) and GLEDHILL (1988).

${ }^{11}$ For more information of the evolution of the BJQ, see DE PROPRIS and LAZZERETTI (2007).

${ }^{12}$ For more information, see HORTON (1908) and SMITH (2003). 
${ }^{13}$ Previous contributions that have described the organisation of production in the BJQ include RoCHE (1927), SARGANT FlORENCE (1948) and GILBERT (1972).

${ }^{14}$ This number is the sum of all firms in 1880 and the number of firms that were born from 1880 to 1973.

${ }^{15}$ Firms' births are considered as discrete events since they are computed $\mathrm{at}_{1}, \mathrm{t}_{2}, \mathrm{t}_{3}$, etc. usually corresponding to years, rather than as continuous events, because this would require the exact day, month and year of birth.

${ }^{16}$ The most frequently used model to represent these relationships is the log-quadratic approximation (HANNAN and FREEMAN, 1989; HANNAN and CARROLL, 1992). The log-quadratic approximation applied to the founding rates has the form:

$\lambda(t)=L_{t} / C_{t}=\varphi\left(N_{t}\right) / v\left(N_{t}\right)=\kappa \lambda(t) \exp \left(\theta_{1} N_{t}+\theta_{2} N_{t}^{2}\right)$, with hypotheses: $H_{1}: \theta_{1}>0 ; H_{2}: \theta_{2}<0$. $\mathrm{L}_{\mathrm{t}}$ captures the legittimation process, and $\mathrm{C}_{\mathrm{t}}$ the competition process. This means that the effect of density due to $N_{t}$, namely the first-order derivative of density, is positive but less than one; whereas the second-order derivative due to $N_{t}^{2}$ is negative. The relationship is non-monotonic and has the form of an inverse- $\mathrm{U}$ with a maximum at: $N_{\lambda}^{*}=-\theta_{1} / 2 \theta_{2}$. Other models to represent these relationships are the generalised-Yule models $(G Y)$ and the log-quadratic approximation model. However, some authors have demonstrated how these latter models do not always offer convergent estimates (HANNAN and FREEMAN, 1989; HANNAN and CARROLL, 1992). In case the Poisson distribution model does not adequately fit the model (because it does not pick up the tendency of the founding rate to vary faster than its average - over-dispersion), the negative binomial model might fit the relation better. Nevertheless, a valuation of the variance of the estimated of the Poisson regression does not reveal high levels of over-dispersion.

17 Period variables have been computed as dummy variables each covering 15 years: 1881-1895, 1896-1910, 1911-1925, 1926-1940, 1941-1955 and 1956-1970.

${ }^{18}$ In density dependence models, it is often the case that populations' characteristics are considered as independent variables. In particular, when analysing firm birth in a population, it is reasonable to verify whether the firms' founding rate at time $t$ is correlated with the lagged variable at $t-1$. A large wave of firms' births at time $t$ can increase the founding rate due to imitation processes, but at the same time, it can hinder the birth of new firms due to the depletion of resources that competition process es have put in motion. Again the firm founding rate can be drawn as an inverse U (DELACROIX and CARROLL, 1983).

${ }^{19}$ To calculate the multiplier of the founding rate we consider the two parameters of the density setting equal to 0 the covariates. This is given by the ratio of the value of density function over the value the density function takes at $\mathrm{N}_{\text {MIN }}$. 